\title{
The Role of the U.S. Army in Asia
}

Thomas J. Bickford, Lisa Hannett, Edward Skolnick, Albert S. Willner CNA CHINA中studies

May 2015

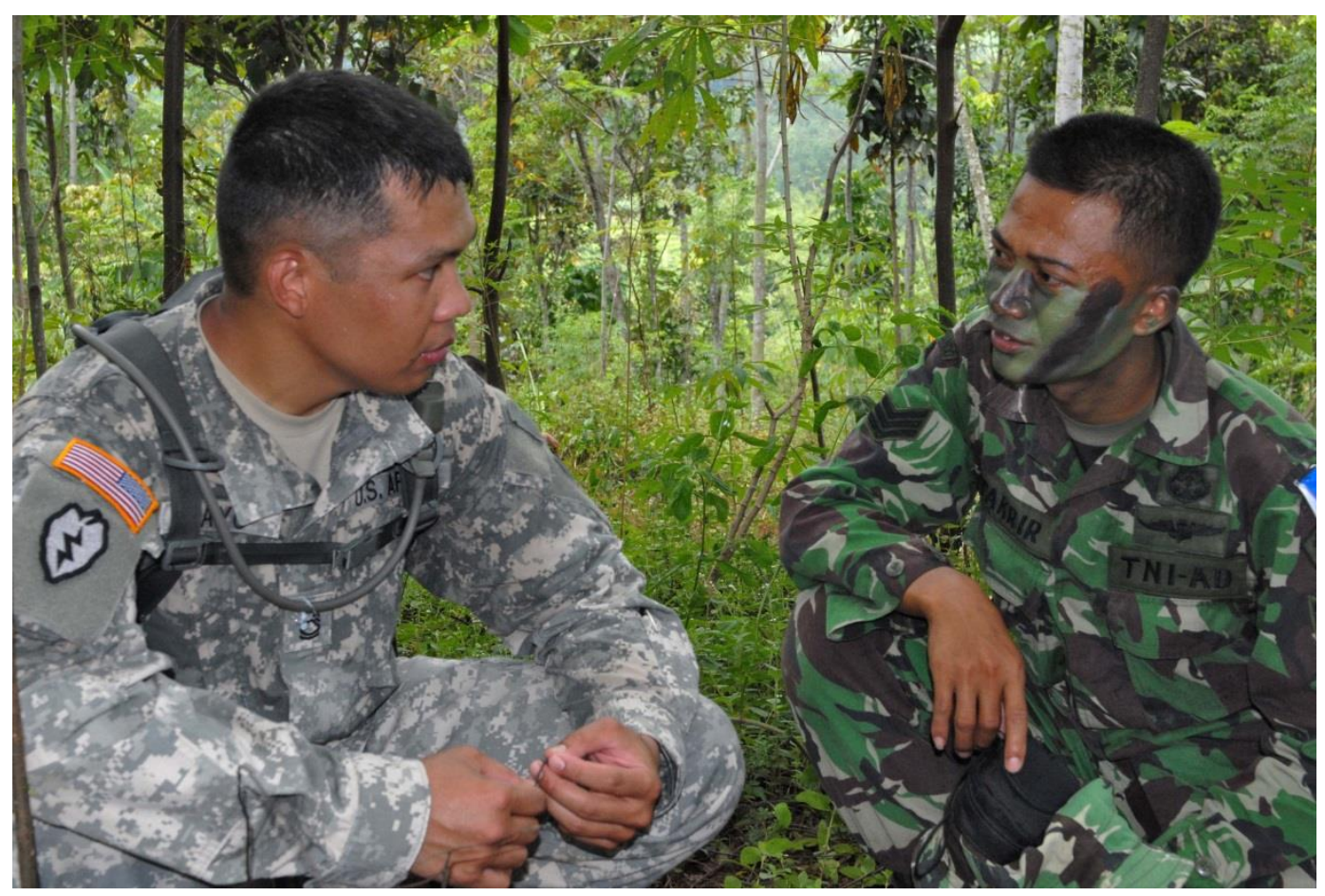




\section{Report Documentation Page}

Form Approved

OMB No. 0704-0188

Public reporting burden for the collection of information is estimated to average 1 hour per response, including the time for reviewing instructions, searching existing data sources, gathering and maintaining the data needed, and completing and reviewing the collection of information. Send comments regarding this burden estimate or any other aspect of this collection of information,

including suggestions for reducing this burden, to Washington Headquarters Services, Directorate for Information Operations and Reports, 1215 Jefferson Davis Highway, Suite 1204, Arlington

VA 22202-4302. Respondents should be aware that notwithstanding any other provision of law, no person shall be subject to a penalty for failing to comply with a collection of information if it

does not display a currently valid OMB control number.

\begin{tabular}{|c|c|c|}
\hline $\begin{array}{l}\text { 1. REPORT DATE } \\
\text { MAY } \mathbf{2 0 1 5}\end{array}$ & 2. REPORT TYPE & $\begin{array}{l}\text { 3. DATES COVERED } \\
\mathbf{0 0 - 0 0 - 2 0 1 5} \text { to 00-00-2015 }\end{array}$ \\
\hline \multirow{3}{*}{\multicolumn{2}{|c|}{ The Role of the U.S. Army in Asia }} & 5a. CONTRACT NUMBER \\
\hline & & 5b. GRANT NUMBER \\
\hline & & 5c. PROGRAM ELEMENT NUMBER \\
\hline \multirow{3}{*}{\multicolumn{2}{|c|}{ 6. AUTHOR(S) }} & 5d. PROJECT NUMBER \\
\hline & & 5e. TASK NUMBER \\
\hline & & 5f. WORK UNIT NUMBER \\
\hline \multicolumn{2}{|c|}{$\begin{array}{l}\text { 7. PERFORMING ORGANIZATION NAME(S) AND ADDRESS(ES) } \\
\text { CNA Analysis \& Solutions,3003 Washington } \\
\text { Boulevard,Arlington,VA,22201 }\end{array}$} & $\begin{array}{l}\text { 8. PERFORMING ORGANIZATION } \\
\text { REPORT NUMBER }\end{array}$ \\
\hline \multirow{2}{*}{\multicolumn{2}{|c|}{ 9. SPONSORING/MONITORING AGENCY NAME(S) AND ADDRESS(ES) }} & 10. SPONSOR/MONITOR'S ACRONYM(S) \\
\hline & & $\begin{array}{l}\text { 11. SPONSOR/MONITOR'S REPORT } \\
\text { NUMBER(S) }\end{array}$ \\
\hline
\end{tabular}

12. DISTRIBUTION/AVAILABILITY STATEMENT

Approved for public release; distribution unlimited

13. SUPPLEMENTARY NOTES

14. ABSTRACT

In January 2012, the Obama administration announced a rebalance to the Asia-Pacific region. Changes in land power objectives and requirements mean that the U.S. Army will face different demand signals in the coming years, which in turn will affect how it needs to posture itself for success. U.S. national security objectives, a changing security environment, and evolving regional interests and expectations will influence the Army???s role and impact. This study is meant to help the Army think about its future role in the Asia-Pacific region.

15. SUBJECT TERMS

\begin{tabular}{|c|c|c|c|c|c|}
\hline \multicolumn{3}{|c|}{ 16. SECURITY CLASSIFICATION OF: } & 17. LIMITATION OF & 18. NUMBER & 19a. NAME OF \\
\hline $\begin{array}{c}\text { a. REPORT } \\
\text { unclassified }\end{array}$ & $\begin{array}{l}\text { b. ABSTRACT } \\
\text { unclassified }\end{array}$ & $\begin{array}{c}\text { c. THIS PAGE } \\
\text { unclassified }\end{array}$ & $\begin{array}{c}\text { Same as } \\
\text { Report (SAR) }\end{array}$ & 96 & \\
\hline
\end{tabular}




\section{CNA}

This document contains the best opinion of CNA at the time of issue.

\section{Distribution}

Unlimited distribution. Specific authority: N00014-1 1-D-0323.

Copies of this document can be obtained through the Defense Technical Information Center at www.dtic.mil or contact CNA Document Control and Distribution Section at 703-824-2123.

Photography Credit: Staff Sgt Joann Moravac, USARPAC PAO. USARPAC Warrior Leader Course for Indonesian Sergeants. U.S. Army website: http://www.army.mil/article/18992

Approved by:

May 2015

\section{Davioly. Tuntelstein}

David Finkelstein

Vice-President and Director

CNA China Studies 


\section{Abstract}

In January 2012, the Obama administration announced a rebalance to the Asia-Pacific region. Changes in land power objectives and requirements mean that the U.S. Army will face different demand signals in the coming years, which in turn will affect how it needs to posture itself for success. U.S. national security objectives, a changing security environment, and evolving regional interests and expectations will influence the Army's role and impact. This study is meant to help the Army think about its future role in the Asia-Pacific region. 
This page intentionally left blank. 


\section{Executive Summary}

This study, The Role of the U.S. Army in Asia, is meant to help the U.S. Army think about how best to support U.S. national security objectives, the joint force, the U.S. interagency, and allies and partners in the Asia-Pacific region. The study's key findings are summarized as follows:

The U.S. Army has a critical and varied role in the Asia-Pacific region that will require it to engage a wide range of capabilities. While preparing to fight in Korea remains its most critical planning and readiness challenge, the Army's day-to-day efforts in the region will focus heavily on meeting a myriad of enabling and shaping requirements.

- Fight. The U.S. Army must be a credible land power in order to deter aggression and meet potential threats that the United States may face in the region. In particular, the Army must be prepared to defeat a determined adversary in Korea-any conflict there would inevitably involve significant land forces.

- Enable. At the strategic, operational, and tactical levels, the U.S. Army needs to continue to bring its critical enabling capabilities to the region in order to support the U.S. national command authority and the combatant commander. These capabilities include air and missile defense, engineers, communications, and logistics.

- Shape. The U.S. Army's day-to-day engagement plays a fundamental role in shaping the strategic and operational security environment. Whether operating in the Philippines, sending cadets to China or Taiwan, carrying out National Guard exchanges with Cambodia, exercising with the Japanese, or placing an attaché in Burma, the Army's shaping role is vital to communicating intent and influencing others in the region to address shared interests.

\section{The Asia-Pacific strategic environment}

Key features of the strategic environment dictate that the U.S. Army be able to do three critical things: (1) surge forces when unpredictable situations arise; 
(2) provide flexible responses to meet diverse contingencies; and (3) apply diverse and relevant regional expertise.

- The region is rife with potential flashpoints, making surge capacity essential. Some, such as Korea, are traditional; others, involving humanitarian assistance and disaster relief, are non-traditional. Tailored force-flow packages, made up of permanent or temporary forces in theater at any particular time, would be of significant value in meeting surge requirements.

- The strategic landscape is changing rapidly, making flexibility essential. Demand signals from the region will shift-and, with the rebalance, demand signals from the U.S. national command authority and the combatant commander will likely shift as well.

- The region hosts persistent physical and human domain challenges, such as (1) the tyranny of distance, (2) enduring historical legacies, (3) domestic political factors, (4) differing capabilities and needs among allied and partner armies, and (5) a wide range of cultures and languages. All of these features complicate interactions and have the potential to influence any operation, action, or activity that the U.S. Army undertakes in the region. An important implication is that success in Asia requires regional and country-specific expertise.

- Land-based non-traditional security threats are an increasingly important concern. The need for responses to these threats-including internal security assistance, humanitarian assistance, disaster relief, response to pandemics, and coastal anti-ship and peacekeeping requirements-will generate significant demands on the U.S. Army for engagement, training, and support.

- China's rise will significantly impact the strategic environment in which the U.S. Army will operate. On the one hand, the region's concerns about China have the potential to increase the demand signal for a stronger Army presence. On the other hand, concerns about China's rise also have the potential to limit the degree to which some countries are willing to get close to the Army.

- Asia-Pacific countries are reassessing their security needs and the future role of their ground forces. Data collected for this project indicate that few countries anticipate the need to prepare for large-scale, conventional ground force operations. Instead, they have continuing concerns about internal stability and non-traditional security challenges. The U.S. Army will have to adjust to the changing demand signals and be flexible in finding ways to meet both its own needs and those of its partners. 


\section{Select key challenges}

Non-traditional security requirements will significantly tax the U.S. Army in theater.

- The U.S. Army is likely to see greater interest by Asia-Pacific countries in exercises and other activities that focus on counterterror, humanitarian assistance, disaster relief, pandemic response, transnational crime, and peacekeeping operations. The Army's capability to plan, its capacity to engage others, and its ability to resource multiple efforts to meet varied needs will all be stressed.

U.S. Army operations, actions, and activities, as well as the perceptions they create, will need to be carefully managed and communicated.

- Consequently, strategic communications will be critical in helping the U.S. Army reassure and/or deter regional actors as needed.

A major challenge for the U.S. Army in Asia is ensuring that its presence is credible and effective, particularly in Southeast Asia.

- U.S. Army forces in Korea and Japan provide a visible and persistent forward presence. The challenge will be to make sure that other forces, whether regionally aligned or temporarily assigned, are seen as enduring rather than ephemeral, and that this presence consistently reinforces the U.S. commitment in the region.

Building and sustaining the right mix of Asia-Pacific regional expertise will be of paramount importance and is likely to be a challenge for the U.S. Army personnel system.

- The U.S. Army's Foreign Area Officer (FAO) program remains the premier example of how to build and apply regional military-political expertise. A challenge for the Army will be to determine how best to train, assign, promote, and retain FAOs to meet changing U.S. priorities in the Asia-Pacific region. Does the Army have the right mix of Asia-Pacific FAOs?

- The U.S. Army should more fully leverage the expertise of personnel other than FAOs. Are non FAOs-to include officers, NCOs, enlisted soldiers, and civilians-being developed and assigned in a way that strengthens the Army's capabilities in Asia to support service, joint, and interagency requirements? 


\section{Recommendations}

We recommend that the U.S. Army take the following actions:

\section{Revisit capacity.}

Revisit the balance of "fight, enable, and shape" capabilities it needs in order to meet its Asia-Pacific requirements.

- If it has not done so, the U.S. Army should conduct an Army-wide review to assess what operational units and institutional organizations are specifically doing both in theater and in the continental United States. The Army could use this review to re-examine (1) what assets are available for use, (2) whether they are properly aligned, and (3) where the Army will need to take risk.

Leverage different ways it can maintain forward presence and visibility in the region.

- With the assignment of a four-star general to lead the U.S. Army Pacific (USARPAC) and the introduction of innovative approaches such as Pacific Pathways, new means are available to leverage capability. The U.S. Army should take a new look at how best to leverage (1) individual and unit rotations, (2) temporary deployments, (3) attaché activities, (4) security cooperation entities, (5) institutional exchanges, (6) video teleconferences, and (7) synthetic training capabilities. By doing so, it can optimize its efforts to assure presence, especially among key partners throughout Southeast Asia.

Work with the Office of the Secretary of Defense and the joint community to revisit the location and composition of pre-positioned (PREPO) equipment so that it is closer to where it will most likely be needed in the evolving operational environment.

The U.S. Army should continue to push for off-shore prepositioning, especially with regard to Southeast Asia and South Asia, to reset the theater and PREPO stocks with engagement requirements and non-traditional threats in mind.

Manage and communicate future U.S. Army force posture changes with an eye to how these will be perceived in the region.

- Especially within the context of the rebalance to Asia and persistent concerns about U.S. commitment, any reductions or realignments of U.S. Army forces in Asia should be accompanied by a solid strategic communications plan. 


\section{Build processes and further develop relationships.}

Identify a principal entity to coordinate, collect, analyze, and disseminate U.S. Army data on regional engagement.

- Do so in a way that allows operational units and institutional organizations to build on engagement activities and set up subsequent exchanges for success.

Re-examine how best to synchronize U.S. Army efforts in the Asia-Pacific region.

- As the U.S. Army participates in a host of operational and institutional engagements with multiple partners, increased coordination among organizations will be instrumental in maximizing the Army's unity of effort and impact in the region.

Develop standard or cross-Army metrics and methodologies to measure success in an engagement and assess its effects on shaping.

- The results of these assessments should be disseminated and incorporated into plans for future operational and institutional engagements.

Leverage U.S. Army experiences in Afghanistan and Iraq when reaching out to armies that need counterterrorist, counterinsurgency, and internal security training.

- Regional militaries are interested in engaging with the U.S. Army because it is viewed as being one of the best and a "partner of choice." In dealing with regional armies, the Army should highlight what it can bring based on its experiences.

Reinforce success by expanding the Army National Guard (ARNG) State Partnership Program (SPP) in the Asia-Pacific region beyond its current seven ARNG-country relationships.

- As a civil-military organization, the Army National Guard, through its SPP, is uniquely positioned to promote whole-of-society, cooperative engagements that allow the Army to interact with regional civilian authorities where appropriate.

\section{Build and retain critical regional expertise.}

Re-examine the Asia-Pacific FAO program to make sure the U.S. Army has the right mix of FAOs needed to support its ability to fight, enable, and shape.

- Such an assessment should revisit whether the current system to identify, train, assign, and retain FAOs is meeting evolving service, joint, and 
interagency needs. The increase of non-traditional demands and requirements in South and Southeast Asia should be considered in any decisions to realign FAOs who are being trained and assigned to the region.

Reassess ways to further build non-FAO regional expertise.

- As there is unlikely to be significant growth in the number of FAOs available for Asia in the near future, the U.S. Army should also identify how best to promote regional expertise among non-FAO personnel-including officers, NCOs, enlisted soldiers, and civilians-by developing, assigning, and retaining them in a way that boosts the Army's capabilities in Asia.

Revisit how ROTC and USMA cultural and foreign language immersion programs can play a greater role in building regional expertise.

- The U.S. Army may be able to build its future regional expertise by identifying cadets involved in Asia-Pacific exchange programs, joint exercise support, and language training, and finding ways to build on their experiences.

Expand the reading lists of the Chief of Staff of the Army and other commands, to include books and articles aimed at improving their understanding of the history, culture, and current issues relevant to the Asia-Pacific region.

- The U.S. Army has been focused on the wars in Afghanistan and Iraq. As it shifts to support the rebalance to Asia, its officers, enlisted personnel, and civilians will need to be more cognizant of the strategic environment and the challenges they will be facing. 


\section{Contents}

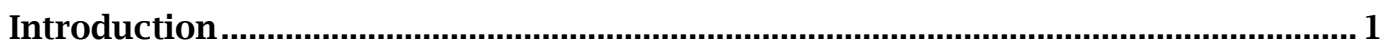

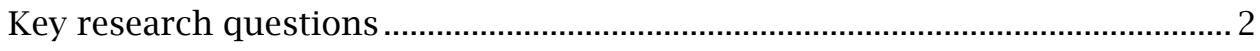

Research approach....................................................................................... 2

Scope and limitations ..................................................................................... 5

U.S. national security objectives and the Asia-Pacific region .................................10

U.S. national security objectives ....................................................................... 11

U.S. national security objectives and the Asia-Pacific region ............................13

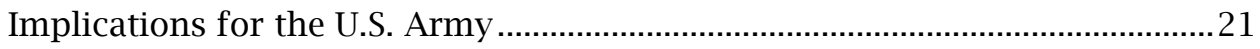

The strategic landscape in the Asia-Pacific region ...................................................25

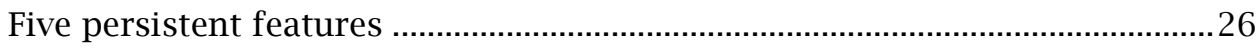

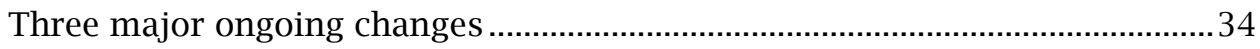

A mix of traditional and non-traditional security threats...................................4

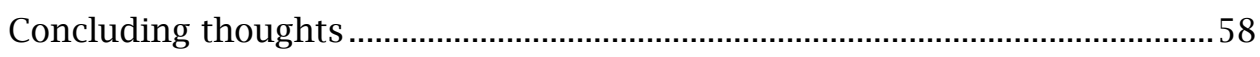

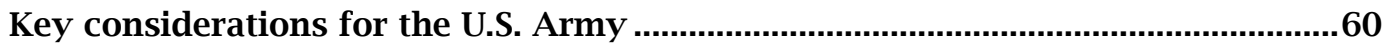

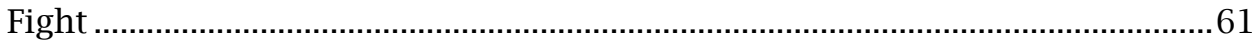

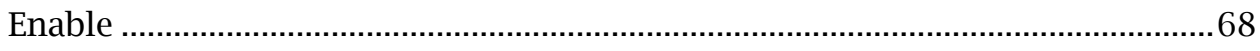

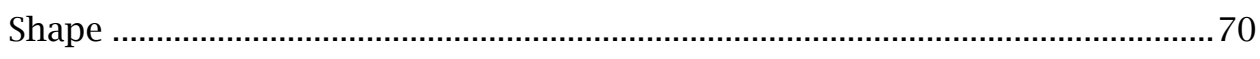

Concluding thoughts and recommendations .....................................................76 
This page intentionally left blank. 


\section{Glossary}

\begin{tabular}{ll} 
A2/AD & Anti-Access/Area Denial \\
AOR & Area of Responsibility \\
ARNG & Army National Guard \\
ASEAN & Association of Southeast Asian Nations \\
CJTF & Combined Joint Task Force \\
COCOM & Combatant Command \\
CONUS & Continental United States \\
DMZ & Demilitarized Zone \\
DoD & Department of Defense \\
EUCOM & U.S. European Command \\
FAO & Foreign Area Officer \\
FID & Foreign Internal Defense \\
FORSCOM & U. S. Forces Command \\
HA/DR & Humanitarian Assistance/Disaster Relief \\
HQDA & Headquarters, Department of the Army \\
MARFORPAC & U.S. Marine Forces, Pacific \\
NCO & Noncommissioned Officer \\
NEO & Noncombatant Evacuation Operation \\
OSD & Office of the Secretary of Defense \\
PKO & Peacekeeping Operation \\
RAF & Regionally Aligned Forces \\
SPP & State Partnership Program \\
TRADOC & U.S. Training and Doctrine Command \\
USARJ & U.S. Army, Japan \\
USARPAC & U.S. Army, Pacific \\
USCENTCOM & U.S. Central Command \\
USFK & U.S. Forces, Korea \\
USPACOM & U.S. Pacific Command \\
USSOCPAC & U.S. Special Operations Command, Pacific \\
WMD & Weapons of Mass Destruction \\
& \\
\hline
\end{tabular}


This page intentionally left blank. 


\section{Chapter 1: Introduction}

In January 2012 the President of the United States and the secretary of defense issued Sustaining U.S. Global Leadership: Priorities for $21^{\text {st }}$ Century Defense, which promulgated new strategic guidance for the Department of Defense and the military services. ${ }^{1}$ Prominent among several important decisions in the guidance is a renewed emphasis on being able to secure growing U.S. national interests in the Asia-Pacific region. To quote from the paper, "While the U.S. military will continue to contribute to security globally, we will of necessity rebalance towards the Asia-Pacific region" [italics in the original]. ${ }^{2}$ The region is of vital importance to U.S. economic, political, and security interests, and the disposition of American military power needs to reflect that importance.

Any rebalance to Asia will necessarily involve a land power component. The U.S. Army has had a permanent presence defending U.S. national interests in the AsiaPacific region since 1898, during which time it has conducted some 63 campaigns. $^{3}$ Today, the Army still must be able to respond to traditional and non-traditional security threats, deter aggression, uphold commitments and responsibilities to allies and partners, and shape the environment. In short, the question is not whether there is a role for the Army in Asia, but what that role is-especially in a post-Afghanistan environment.

This study is meant to help the U.S. Army think about how best to support U.S. national security objectives, the joint force, the U.S. interagency, and allies and partners in the Asia-Pacific region.

\footnotetext{
${ }^{1}$ United States Department of Defense, Sustaining U.S. Global leadership: Prospects for $21^{\text {st }}$ Century Defense, January 2012, last accessed August 16, 2013, at http://www.defense.gov/news/ defense_strategic_guidance.pdf (hereafter referred to as the 2012 Defense Strategic Guidance).

2 Department of Defense, 2012 Defense Strategic Guidance, p. 2.

${ }^{3}$ By way of comparison, since 1775 , the U.S. Army has conducted 78 campaigns in North, Central, and South America, 31 in Europe and Africa, and 8 in the Middle East and Southwest Asia. See Association of the United States Army, Torchbearer National Security Report, The U.S. Army in the Pacific: Assuring Security and Stability, April 2013, p. 5. For a concise history of the role of the U.S. Army in the Pacific, see James C. McNaughton, The U.S. Army in the Pacific: A Century of Engagement, Center for Military History, United States Army, 2012.
} 


\section{Key research questions}

The study asks four key questions:

- What U.S. national security objectives in the Asia-Pacific region are relevant to the U.S. Army?

- What key elements in the security environment in the Asia-Pacific are relevant to the U.S. Army?

- What key attributes does the U.S. Army bring to support U.S. national security objectives, and which ones apply to the particular concerns of the region?

- What are the key considerations for the U.S. Army in securing U.S. national objectives in the region?

\section{Research approach}

In order to address these key questions, this study draws on a wide range of U.S. government sources, non-government studies, interviews, and other data to develop our analysis. These sources include the following:

- U.S. government documents and official statements. We conducted an extensive review of national-level strategic documents such as the 2010 U.S. National Security Strategy and the 2012 U.S. Global Leadership: Prospects for 21st Century Defense. ${ }^{4}$ We also drew on documents from the United States Pacific Command (USPACOM) and its component commands, such as the U.S. Army, Pacific (USARPAC), including USPACOM Strategy and Partnering in the Pacific Theater: Assuring Security and Stability through Strong Army Partnerships. ${ }^{5}$ We reviewed U.S. Army publications such as The United States

\footnotetext{
${ }^{4}$ The White House, 2010 National Security Strategy, May 2010, last accessed February 25, 2013, at http://www.whitehouse.gov/sites/default/files/rss_viewer/national_security_Strategy.pdf; Department of Defense, 2012 Defense Strategic Guidance.

5 United States Pacific Command, USPACOM Strategy, available at www.pacom.mil/aboutuspacom/2013-uspacom-strategy.shtml, last accessed July 22, 2013; and Partnering in the Pacific Theater: Assuring Security and Stability through Strong Army Partnerships (Honolulu: United States Army, Pacific, Apr. 26, 2012), last accessed Feb. 5, 2013, at http://www.usarpac.army.mil/pdfs/Partnering\%20in\%20the\%20Pacific\%20Theater.pdf.
} 
Army Capstone Concept $^{6}$ We supplemented the material from these documents with a review of official statements and testimonies by senior military and civilian officials, such as former national security advisor Thomas E. Donilon and USPACOM commander Admiral Samuel J. Locklear. ${ }^{7}$ These materials were used to provide insight into U.S. national security objectives in the Asia-Pacific region and USPACOM and into component commands' approach to achieving those objectives. U.S. Army documents were used to help identify Army programs and capabilities that are relevant to U.S. national security needs in the Asia-Pacific region.

- Interviews with U.S. civilian and military officials. We also conducted interviews with a wide range of U.S. Department of Defense personnel. In order to get inside the U.S. Army both institutionally and operationally, we conducted interviews with officials in the Office of the Secretary of Defense (OSD); USPACOM; United States Forces Korea (USFK); Headquarters, Department of the Army (HQDA); United States Army National Guard (ARNG); United States Army Pacific (USARPAC); U.S. Marine Forces Pacific (MARFORPAC); United States Army Training and Doctrine Command (TRADOC); United States Army Forces Command (FORSCOM); United States Army Combined Arms Center (USACAC); United States Army Japan (USARJ); Eighth Army; I Corps; and 25 $5^{\text {th }}$ Infantry Division. These interviews helped confirm and broaden our understanding of the implementation of national security objectives in the region and areas where the Army can contribute as a service, as part of the joint force, and as part of the interagency. We also interviewed U.S. State Department personnel and U.S. embassy officials serving in Asia.

- Interviews with U.S. subject matter experts. In addition to interviews with U.S. government personnel, the authors interviewed a number of subject matter experts from outside the U.S. government, such as academics and think tank analysts. These interviews provided unofficial and alternative views that

\footnotetext{
${ }^{6}$ U.S. Army Training and Doctrine Command, The U.S. Army Capstone Concept, PAM 525-3-0, 19 December 2013.

${ }^{7}$ See, for example, "Remarks By Tom Donilon, National Security Advisor to the President: 'The United States and the Asia-Pacific in 2013,"” The Asia Society, New York, March 11, 2013, at White House website, http://www.whitehouse.gov/the-press-office/2013/03/11/remarks-tomdonilon-national-security-advisory-president-united-states-a, last accessed March 31, 2013. See also "The Posture of the U.S. Pacific Command and U.S. Strategic Command," including the statement of Admiral Samuel J. Locklear, U.S. Navy, Commander, U.S. Pacific Command before the House Armed Services Committee, March 5, 2013, last accessed March 6, 2013, at http://www.pacom.mil/commander/ statements-testimony/20130305-hasc-uspacom-posturetranscript.shtml.
} 
were related to the study and had the potential to offer fresh perspectives on relevant issues.

- Existing studies. The authors also examined a number of existing studies and journal articles by non-government subject matter experts that looked at issues related to current and possible future roles for the U.S. Army, such as Beyond the Last War, produced by the Center for Strategic and International Studies, and U.S. Military Presence Overseas: What Are the Strategic Choices? published by RAND. ${ }^{8}$ These were used to supplement the analysis and research for this study and to provide a better understanding of the range of views beyond those of the Department of Defense and the Department of the Army.

- Asia-Pacific government documents and statements by officials. In addition to U.S. sources, this study examined a number of official statements and documents produced by governments in the Asia-Pacific region-for example, defense white papers from Australia, Japan, and South Korea. ${ }^{9}$ These sources provided authoritative information on how countries in the region view the strategic landscape, what their primary security concerns are, and how they view the role of the U.S. military. These data helped identify potential challenges and opportunities for the role of the U.S. Army in the Asia-Pacific region.

- Interviews with Asia-Pacific officials and subject matter experts. In order to supplement the documentary evidence, the authors also conducted extensive interviews with Asia-Pacific military and civilian government officials and subject matter experts. These interviews were conducted both in the United States and in Asia. ${ }^{10}$ The countries represented by interviewees included but

\footnotetext{
${ }^{8}$ Nathan Freier, Project Director, Beyond the Last War: Balancing Ground Forces and Future Challenges and Risk in USCENTCOM and USPACOM, Center for Strategic and International Studies, April 2013, last accessed June 25, 2013, at http://csis.org/files/publication/130424_ Freier_BeyondLast War_Web.pdf; and Lynn E. Davis, Stacie L. Pettyjohn, Melanie W. Sisson, Stephen M. Worman, and Michael J. McNerney, U.S. Military Presence Overseas: What Are the Strategic Choices? RAND Corporation, 2012, last accessed August 19, 2013, at http://www.rand.org/content/dam/rand/pubs/monographs/2012/RAND_MG1211.sum.pdf.
}

${ }^{9}$ Australian Government, Department of Defence, Defence White Paper 2013, May 3, 2013, last accessed August 17, 2013, at http://www.defence.gov.au/whitepaper2013/; Government of Japan, Ministry of Defense, Defense of Japan 2013, last accessed September 3, 2013, at http://www.mod.go.jp/e/publ/w_paper/pdf/2013/11_Part1_Chapter1_Sec3.pdf; and Republic of Korea, Ministry of National Defense, 2010 Defense White Paper, December 31, 2010, last accessed March 17, 2013, at http://www.mnd.go.kr/cop/pblictn/ selectPublicationUser.do?siteId=mnd_eng\&componentId=51\&categoryId=0\&publicationSeq=583 \&pageIndex=1\&id=mnd_eng_021400000000.

${ }^{10}$ These include extensive interviews conducted in the Philippines, India, Japan, South Korea, and Australia. 
were not limited to China, Japan, India, South Korea, the Philippines, Thailand, Singapore, Vietnam, and Australia. These interviews provided important additional insights into regional views on the Asia-Pacific security environment, especially as it relates to the role of ground forces, U.S. military presence, military-to-military exchanges with the United States, and other issues.

- Asian media and polling data. Finally, as public opinion and domestic politics can and do influence how countries interact with the United States, we looked at select regional media and polling data to assess public attitudes that might be relevant to the U.S. Army. These included receptivity to the presence of U.S. military personnel and, in the case of treaty allies, attitudes toward their country's alliance with the United States.

\section{Scope and limitations}

In order to properly focus the analysis, this study was carefully scoped geographically and analytically.

\section{Time frame}

The time frame for this study is the current year out to 2023. The focus is on the present as combat forces in Afghanistan are being withdrawn and as the U.S. Army increases support for the rebalance to Asia. We limit discussion of potential future concerns to this time frame as that was assessed as a reasonable limit given the data available for the study, most of which is derived from 2013 and earlier.

\section{Geographic scope}

This study focuses on the USPACOM area of responsibility (AOR), shown in figure $1 .{ }^{11}$ While the term "Asia-Pacific" can be used to include Central Asia and Russia as well, we chose to focus only on countries with which USPACOM interacts. As these are the

\footnotetext{
${ }^{11}$ There are 36 countries listed in the USPACOM AOR: Australia, Bangladesh, Bhutan, Brunei, Burma, Cambodia, China, Fiji, India, Indonesia, Japan, Kiribati, Laos, Malaysia, Maldives, Marshall Islands, Micronesia, Mongolia, Nauru, Nepal, New Zealand, North Korea, Palau, Papua New Guinea, Philippines, Samoa, Singapore, Solomon Islands, South Korea, Sri Lanka, Thailand, Timor-Leste, Tonga, Tuvalu, Vanuatu, and Vietnam. Taiwan also comes within the USPACOM AOR but is not regarded as an independent country by the United States.
} 
countries of most importance to the U.S. rebalance to Asia, ${ }^{12}$ we assessed them to be the most relevant to evaluating the role of the U.S. Army in Asia. ${ }^{13}$

Within the USPACOM AOR, we focused on those countries that we assessed as most likely to be important to the U.S. Army:

- The five treaty allies: Australia, Japan, the Philippines, South Korea, and Thailand

- Countries identified in public documents and interviews as being important partners for military engagement, such as China, India, Indonesia, and Vietnam

- Countries identified in public documents and interviews as important security concerns that relate to U.S. Army capabilities, such as North Korea.

\footnotetext{
${ }^{12}$ In discussing the rebalance, the 2012 Defense Strategic Guidance emphasizes the Western Pacific/East Asia, Southeast Asia, and South Asia and the Indian Ocean. See 2012 Defense Strategic Guidance, p. 2.

${ }^{13}$ This does not mean that other parts of Asia were completely ignored. For example, we did note in our analysis that USPACOM, including USARPAC, engages with the Russian military, even though Russia falls within U.S. European Command's (EUCOM's) AOR. It is the authors' understanding that Russian engagement with USPACOM includes liaison via EUCOM. Interviews with U.S. Army officials, December 2012.
} 
Figure 1. USPACOM Area of Responsibility

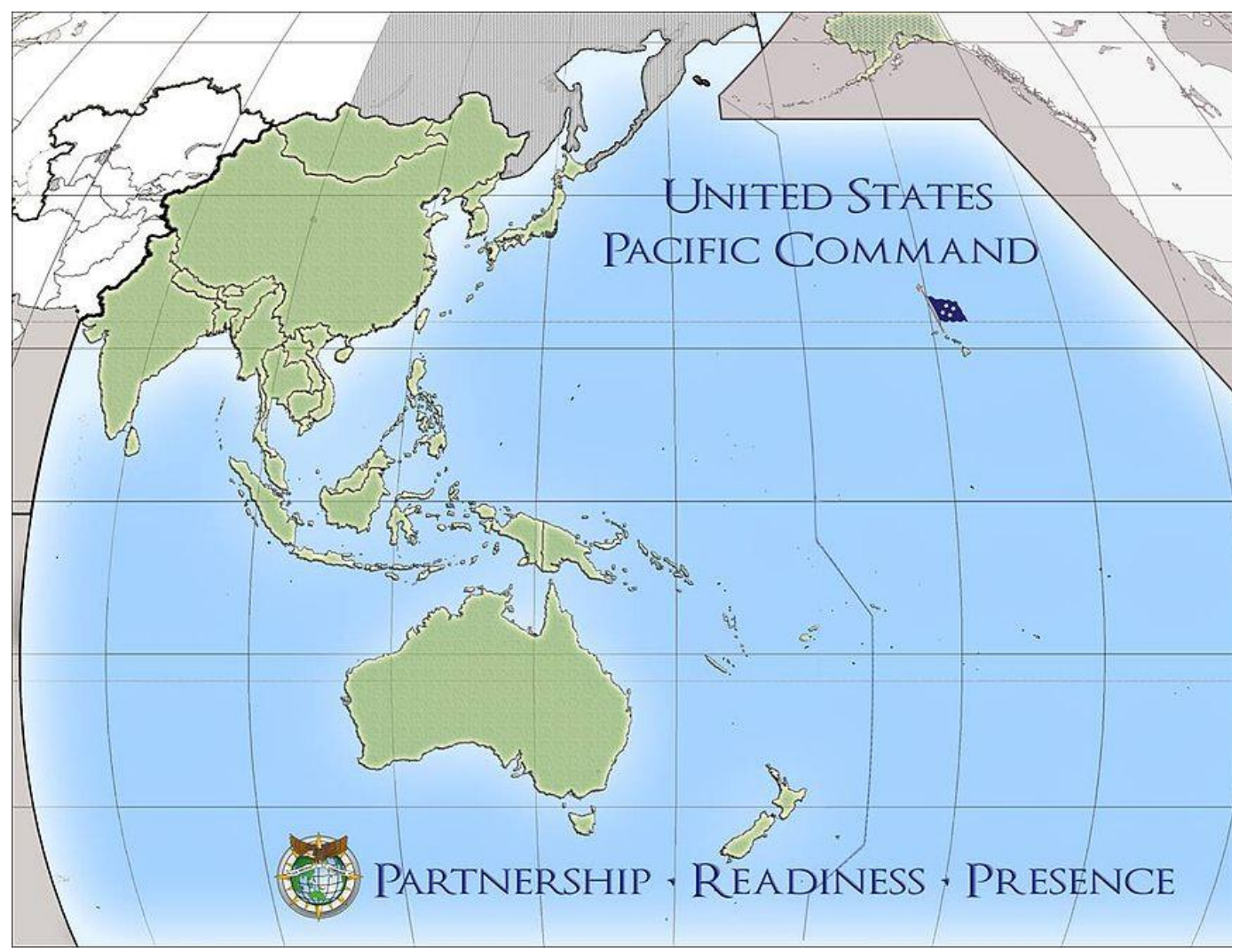

Source: PACOM area of responsibility, USPACOM website, http://www.pacom.mil/aboutuspacom/area-of-responsibility.shtml, accessed October 1, 2013.

\section{Analytic scope}

In order to bound the analytic scope of this study, we must clearly define its focus.

This study is:

- Regionally focused in that it looks only at the Asia-Pacific region as defined above. Our analytic findings are based on the region and do not take into consideration other parts of the globe. While U.S. national security objectives are global, this study is only concerned with their application to Asia and their relevance to the U.S. Army. 
- Concerned with the strategic landscape of the Asia-Pacific region. The goal is to help the reader think about large themes that can shape and impact the U.S. Army's activities and actions throughout the region.

- Focused on the role of the U.S. Army. While the U.S. Marine Corps and U.S. Special Operations Command (USSOCOM) have made important contributions to strategic land power in the region and around the globe, ${ }^{14}$ this study is focused on the Army and is not a comprehensive assessment of land power requirements. The study is informed by interviews with Marine Corps and USSOCOM personnel, and we looked at how these forces are approaching challenges similar to those of the Army; however, this is a study specific to the Army.

- Focused on capabilities that the U.S. Army brings to the joint force and interagency in support of U.S. national security goals in the region. The study recognizes that some capabilities might be critical for the Army's global role but are not necessarily critical in the Asia-Pacific region. The concern here is not with capabilities requirements that are more relevant to other regions or with those that are purely global requirements.

- Concerned with what the U.S. Army might have to do in the region and what capabilities it will need, rather than being a study on force posture. The study makes no analytic judgments on what force structure or posture the Army will need.

The chapters in this report are as follows:

Chapter 1, Introduction: Provides an overview of the objective of the study, key questions, sources, and scope.

Chapter 2, U.S. National Security Objectives and the Asia-Pacific Region: Provides a brief overview and analysis of U.S. national security objectives as they pertain to the role of the U.S. Army in Asia.

Chapter 3, The Strategic Landscape in the Asia-Pacific Region: Provides an analysis of key elements of the strategic landscape that are especially relevant for the U.S. Army. The chapter concludes with a discussion of the implications for the Army and its role in the Asia-Pacific region.

${ }^{14}$ See Strategic Land Power Task Force, Department of Defense, Strategic Land Power White Paper, May 2013; last accessed August 12, 2013, at http://www.ausa.org/news/2013/ Documents/Strategic\%20 Landpower\%20White\%20Paper\%20May\%202013.pdf. 
Chapter 4, Key Considerations for the U.S. Army: Provides a discussion and analysis of what capabilities the Army needs if it is to support the joint force and interagency in securing U.S. national security objectives in the Asia-Pacific region. The chapter also offers final thoughts and conclusions. 


\section{Chapter 2: U.S. National Security Objectives and the Asia-Pacific Region}

U.S. national security objectives have important implications for the role of the U.S. Army in the Asia-Pacific region. U.S. national security objectives broadly define what the U.S. government seeks to achieve, and provide guidance that informs Department of Defense (DoD) policies and the way that the combatant commands (COCOMs) approach their respective areas of responsibility. Assessing U.S. national security objectives, therefore, is critical to identifying the potential demand for the strategic role of land power in achieving those objectives in the Asia-Pacific region.

This chapter provides an analysis of U.S. national security objectives and their implications for the role of the U.S. Army in the Asia-Pacific region. The chapter is divided into three parts:

- First, we provide a broad overview of U.S. national security objectives as articulated in national strategy documents produced by the White House and the Department of Defense. This discussion is used to identify the principal security objectives that the U.S. government seeks to achieve.

- Second, we provide our assessment of how these objectives apply to the AsiaPacific region based on our analysis of USPACOM public documents, statements by senior Department of Defense and Department of State personnel, and interviews with U.S. civilian and military officials at USPACOM, USFK, HQDA, USARPAC, FORSCOM, and TRADOC.

- Third, we provide a summary analysis of the likely implications for the U.S. Army in terms of the demand signals generated by U.S. national security objectives.

This analysis, along with the assessment of the strategic landscape in the following chapter, serves as the basis for assessing what the U.S. Army should consider in order to better support U.S. objectives in Asia and what capabilities it will likely need in the region. 


\section{U.S. national security objectives}

To identify the United States' national security interests, we reviewed four key national strategy documents: the 2010 National Security Strategy; the 2012 Defense Strategic Guidance; The National Military Strategy of the United States of America: Redefining America's Military Leadership, 2011; and the 2010 Quadrennial Defense Review. We also reviewed previous iterations of these documents. ${ }^{15}$ Taken together, these documents provide a framework for understanding national security policy and inform how the services and COCOMs approach their respective areas of responsibility. ${ }^{16}$ These documents thus provide guidance on how the United States government sees global national security objectives with implications for the AsiaPacific, Middle East, and other regions.

Based on our analysis, we assess the following to be the key U.S. national security objectives:

- Defend the U.S. homeland. ${ }^{17}$ The United States must be capable of "deterring and defeating aggression by any potential adversary." ${ }^{18}$ The national strategic

\footnotetext{
${ }_{15} 2010$ U.S. National Security Strategy; 2012 Defense Strategic Guidance; U.S. Department of Defense, The National Military Strategy of the United States of America: Redefining America's Military Leadership, 2011 (hereafter referred to as the 2011 National Military Strategy), available at http://www.army.mil/ info/references/docs/NMS\%20FEB\%202011.pdf; and U.S. Department of Defense, 2010 Quadrennial Defense Review Report, February 2010, last accessed February 25, 2013, at http://www.defense.gov/qdr/images/QDR_as_of_12Feb10_ 1000.pdf. The order of precedence listed comes from the United States Pacific Command's strategy page on its official website. See United States Pacific Command's USPACOM Strategy, last accessed July 22, 2013, at www.pacom.mil/about-uspacom/2013-uspacom-strategy.shtml. The authors also looked at previous versions of these documents to help identify consistent, long-term objectives. Previous iterations of national strategy documents used for this study include: U.S. Department of Defense, 2006 Quadrennial Defense Review, February 6, 2006, last accessed February 25, 2013, at http://www.defenselink.mil/qdr/report/Report20060203.pdf; U.S. Department of Defense, The National Military Strategy of the United States of America: A Strategy for Today; A Vision for Tomorrow, 2004, last accessed February 25, 2012, at http://www.defenselink.mil/news/Mar2005/d20050318nms.pdf; and the White House, 2002 National Security Strategy, September 2002, last accessed February 25, 2013, at http://nssarchive.us/?page_id=32.

${ }^{16}$ See United States Pacific Command's USPACOM Strategy, last accessed July 22, 2013, at www.pacom.mil/about-uspacom/2013-uspacom-strategy.shtml; United States Africa Command, AFRICOM Mission Statement, last accessed August 29, 2013, at http://www.africom.mil/whatwe-do; and United States Central Command, 2013 Force Posture Statement, last accessed August 10, 2013, at http://www.centcom.mil/en/about-centcom/posture-statement/.
}

172012 Defense Strategic Guidance, p. 5; See also United States Department of Defense, the 2011 National Military Strategy, p. 1, last accessed February 2013, at http://www.army.mil/ info/references/docs/NMS\%20FEB\%202011.pdf; 2010 U.S. National Security Strategy; also U.S. Department of Defense, 2010 Quadrennial Defense Review Report, February 2010, pp. v, 17, last accessed February 25, 2013, at http://www.defense.gov/qdr/images/QDR_as_of_ 
documents assess the greatest threats to the U.S. homeland as including terrorism and violent extremism, the proliferation and spread of weapons of mass destruction (WMD), and attacks in the cyber and space domains. ${ }^{19}$

- Ensure American economic prosperity. ${ }^{20}$ As the 2010 National Security Strategy notes, the U.S. economy "serves as the wellspring of American power." ${ }^{21}$ A critical part of maintaining a strong economy is participation in the global economy, including building economic partnerships overseas, ensuring access to markets and transit routes, and guarding against threats to U.S. economic resources. ${ }^{22}$

- Defend and protect U.S. interests and commitments overseas. ${ }^{23}$ These interests and commitments include: upholding the security of allies and partners, including strengthening their capacity to defend themselves and/or to work with the United States for their defense; protecting U.S. citizens, facilities, and other assets overseas; and maintaining access and freedom of movement in order to project power. ${ }^{24}$

- Ensure a safe, stable, prosperous, and rules-based international environment. ${ }^{25}$ U.S. economic and physical security rests, in part, on the maintenance of a rules-based, international system that "encourages the peaceful rise of new powers, economic dynamism, and constructive defense

12Feb10_1000.pdf; U.S. Department of Defense, 2006 Quadrennial Defense Review, February 6, 2006, pp. 24-26, last accessed February 25, 2013, at http://www.defenselink.mil/ qdr/report/Report20060203.pdf; also U.S. Department of Defense, The National Military Strategy of the United States of America: A Strategy for Today; A Vision for Tomorrow, 2004, $\mathrm{p}$. 2, last accessed February 25, 2013, at http://www.defenselink.mil/news/Mar2005/ d20050318nms.pdf; and the White House, 2002 National Security Strategy, September 2002, pp. i, 6, 14, 30, last accessed February 25, 2013, at http://nssarchive.us/?page_id=32.

${ }_{18} 2012$ Defense Strategic Guidance, p. 4; and 2011 National Military Strategy, pp. 8-9.

192012 Defense Strategic Guidance, pp. 1 and 3-4; the 2011 National Military Strategy, pp. 3, 5, 7, and 19; and 2010 National Security Strategy, pp. 17, 23-24, and 27.

${ }^{20} 2012$ Defense Strategic Guidance, pp. 1-3; 2011 National Military Strategy, pp. 10-11; 2010 National Security Strategy, pp. 12-13; 2006 Quadrennial Defense Review, pp. 28, 30; 2004 National Military Strategy, p. 1; 2002 National Security Strategy, pp. 21, 27.

212010 National Security Strategy, p. 2.

222010 National Security Strategy, p. 4; 2012 Defense Strategic Guidance, p. 3; and 2011 National Military Strategy, p. 3.

${ }^{23} 2012$ Defense Strategic Guidance, pp. 1-2; 2010 National Security Strategy, pp. 2-4, and 7.

${ }^{24}$ Ibid.

252012 Defense Strategic Guidance, pp. 1-3; 2011 National Military Strategy, pp. 10-11; 2010 National Security Strategy, pp. 12-13; 2006 Quadrennial Defense Review, p. 28; and 2004 National Military Strategy, p. 1. 
cooperation" and that is consistent with American values. ${ }^{26} \mathrm{~A}$ safe and stable international environment also rests on the ability and willingness of states to cooperate on a wide range of mutual security interests. These include preventing and controlling epidemic disease; addressing the implications of climate change; and addressing trans-national security challenges, such as smuggling, human trafficking, piracy, and terrorism. ${ }^{27}$

- Retain and strengthen the United States' ability to shape the global environment. ${ }^{28}$ Finally, in order for the United States to retain a position of global strength and to maximize its future freedom of action, a key national security objective is to be able to continue to exert leadership while sharing global responsibilities with other countries. This includes maintaining a reputation as a capable partner that lives up to its obligations and is a "partner of choice"; retaining access to the global commons in the maritime, aerospace, and cyberspace domains; strengthening U.S. ability to deter rising states and non-state actors from using new capabilities against the United States and its allies and partners; and maintaining moral leadership through a demonstrated commitment to the values of democracy, human rights, and the rule of law. ${ }^{29}$

\section{U.S. national security objectives and the Asia-Pacific region}

In mapping these broad national security objectives to the Asia-Pacific region, we drew on the 2012 Defense Strategic Guidance, which specifically addresses the region; the USPACOM Strategy, which outlines the command's approach to the region based on the above national strategic documents; public statements by senior U.S. officials such as then deputy secretary of defense Ashton Carter and former national security advisor Thomas Donilon; and interviews with U.S. military and government officials. $^{30}$

\footnotetext{
${ }^{26} 2012$ Defense Strategic Guidance, p. 2; and 2010 National Security Strategy, pp. 12 and 29.

272010 National Security Strategy, p. 34.

${ }^{28}$ Ibid., p. 2-3; 2010 Quadrennial Defense Review, pp. 5-7; 2006 Quadrennial Defense Review, p. 48; and 2004 National Military Strategy, p. v.

${ }^{29} 2011$ National Military Strategy, pp. 3-4; and 2010 National Security Strategy, pp. 2, 36-37, and 41 .

${ }^{30}$ See, for example, 2012 Defense Strategic Guidance; USPACOM Strategy (2013); "Remarks by Tom Donilon, National Security Advisor to the President: "The United States and the Asia-Pacific in 2013'” (2013); and “The U.S. Strategic Rebalance to Asia: A Defense Perspective," as delivered
} 
For the Asia-Pacific region, the single most overriding concern is the link between ensuring economic prosperity and securing a stable and peaceful security environment. As noted in the 2012 Defense Strategic Guidance:

U.S. economic and security interests are inextricably linked to developments in the arc extending from the Western Pacific and East Asia into the Indian Ocean and South Asia, creating a mix of evolving challenges and opportunities. Accordingly, while the U.S. military will continue to contribute to security globally, we will of necessity rebalance toward the Asia-Pacific region. ${ }^{31}$ [Italics in the original]

And, as further elaborated on by Donilon:

...the overarching objective of the United States in the [Asia-Pacific] region is to sustain a stable security environment and a regional order rooted in economic openness, peaceful resolution of disputes, and respect for universal rights and freedoms. To pursue this vision, the United States is implementing a comprehensive, multidimensional strategy: strengthening alliances; deepening partnerships with emerging powers; building a stable, productive, and constructive relationship with China; empowering regional institutions; and helping to build a regional economic architecture that can sustain shared prosperity. These are the pillars of the U.S. strategy.... ${ }^{32}$

Peace, stability, and economic growth in the region, therefore, are essential components of securing the American domestic economy. Asia is increasingly the center of the global economy of the $21^{\text {st }}$ century. ${ }^{33}$ It includes the world's three largest economies-the United States, China, and Japan-which together account for 55 percent of world GDP and 44 percent of total world trade..$^{34}$ In addition, the region contains the rising economies of India and of much of Southeast Asia. The region is a vital market for the United States: it accounted for 61 percent of all U.S. goods ( $\$ 942$

by Deputy Secretary of Defense Ashton B. Carter, August 1, 2012, last accessed August 3, 2012 , at http://www.defense.gov/Speeches/Speech.aspx?SpeechID=1715; and interviews with USPACOM and U.S. Army officials, 2012; and Department of Defense officials, 2013.

312012 Defense Strategic Guidance, p. 2.

32 "Remarks by Tom Donilon, National Security Advisor to the President: 'The United States and the Asia-Pacific in 2013'” (2013).

${ }^{33}$ United States Pacific Command, USPACOM Strategy (2013); and 2012 Defense Strategic Guidance, p. 2.

34 "What is Asia-Pacific Economic Cooperation?" official website of the Asia-Pacific Economic Cooperation (APEC), http://www.apec.org/about-us/about-apec.aspx, accessed October 31, 2013. 
billion) and 75 percent of all agricultural products ( $\$ 106$ billion) exported in 2012. ${ }^{35}$ The Asia-Pacific region is also important for U.S. overseas investment: direct investment in Southeast Asia alone amounted to $\$ 302.7$ billion in $2011 .{ }^{36}$ In addition, the region contains vital sea and air transit routes that are critical to the smooth flow of world trade and the U.S. economy. Moreover, the U.S. government sees a stable economic environment as being advantageous to the region, which in turn benefits the United States and its domestic economy. ${ }^{37}$ Disruptions to the economic well-being of this region, whether as a result of conflict or as a result of natural disaster, have the potential to negatively impact the economy of the United States. The entire region-East Asia, Southeast Asia, South Asia, the Western Pacific, and the Indian Ocean-and its economic growth and stability are key to U.S. economic prosperity.

Ensure a safe, stable, prosperous, and rules-based international environment. As the earlier quote from Donilon suggests, achieving a stable, prosperous, and rulesbased environment is a major objective in the Asia-Pacific region. A wide range of goals support this overall objective, including:

- Maintaining positive engagement with China in order to influence its rise and support its inclusion in international systems and norms-though there are concerns about its lack of transparency and intent. ${ }^{38}$ A cooperative U.S.-China partnership is currently seen as "essential" for peace, regional stability, and global security. ${ }^{39}$

- Ensuring peace and stability on the Korean Peninsula by deterring North Korean aggression and working with China, South Korea, Japan, and Russia to encourage the de-nuclearization of North Korea. ${ }^{40}$

${ }^{35}$ Office of the United States Trade Representative, "The United States in the Trans-Pacific Partnership," last accessed on July 30, 2013, at www.ustr.gov/.

36 U.S. Direct Investment Abroad, last accessed August 3, 2013, at www.bea.gov/international/dilusdbal.htm.

37 See 2010 National Security Strategy, p. 4; 2012 Defense Strategic Guidance, p. 3; 2011 National Military Strategy, p. 3. See also remarks made by then deputy secretary of defense Ashton B. Carter, "Defense Priorities in an Era of Constrained Budgets," at the CNAS annual conference on June 12, 2013. Video last accessed August 10, 2013, at http://www.cnas.org/node/10763.

382012 Defense Strategic Guidance, p. 2; United States Pacific Command, USPACOM Strategy (2013).

${ }^{39}$ United States Pacific Command, USPACOM Strategy (2013); and "Remarks by Tom Donilon, National Security Advisor to the President: 'The United States and the Asia-Pacific in 2013'” (2013).

${ }^{40}$ Ibid. 
- Continuing to engage and develop relations with emerging powers such as India and Indonesia, as well as further deepening partnerships with countries around the region, and helping build the capacity of these countries to deal with their security problems. ${ }^{41}$

- Countering proliferation of weapons of mass destruction (WMD). ${ }^{42}$

- Working with regional institutions such as the Association of Southeast Asian Nations (ASEAN), to promote stability, economic cooperation, and the peaceful resolution of disputes, such as those in the South China Sea. ${ }^{43}$

- Countering terrorism. ${ }^{44}$

- Responding to natural and man-made disasters. ${ }^{45}$

Defending and protecting U.S. interests and commitments overseas. In addition to maintaining prosperity and a stable international order, defending and protecting U.S. interests and commitments overseas is also an important objective that applies to the Asia-Pacific region. This includes the ability to protect U.S. access to resources and, if need be, to protect the lives and property of U.S. citizens abroad. The State Department estimated in late 2011 that there were approximately 864,000 Americans living in East Asia and the Pacific and a further 212,000 living in South Central Asia. ${ }^{46}$ U.S. citizens studying abroad and travelling for business or pleasure push these totals much higher.

The United States also has commitments to five mutual defense treaty partnersJapan, South Korea, Thailand, the Philippines, and Australia-as well as a strong

\footnotetext{
${ }^{41}$ Ibid.; and Carter, "Defense Priorities in an Era of Constrained Budgets."

${ }^{42}$ United States Pacific Command, USPACOM Strategy (2013); and "Statement of Admiral Samuel J. Locklear, U.S. Navy, Commander, U.S. Pacific Command Before the House Armed Services Committee on U.S. Pacific Command Posture," transcript from the House Armed Services Committee, 5 March 2013, http://www.pacom.mil/commander/ statementstestimony/20130305-hasc-uspacom-posture-transcript.shtml.

${ }^{43}$ United States Pacific Command, USPACOM Strategy (2013); and "Remarks by Tom Donilon, National Security Advisor to the President: 'The United States and the Asia-Pacific in 2013'” (2013).

${ }^{44}$ United States Pacific Command, USPACOM Strategy (2013).

${ }^{45}$ Ibid.

${ }^{46}$ State Department estimates as cited by the Association of Americans Resident Overseas, "6.32 million Americans (excluding military) live in 160-plus countries," last accessed August 31, 2013, at http://www.aaro.org/about-aaro/6m-americans-abroad.
} 
interest in enhancing relations and security partnerships with India, Indonesia, Singapore, Vietnam, Malaysia, and others. ${ }^{47}$

Securing the homeland. Protecting the homeland is also a key national security objective that applies to the Asia-Pacific region. In part, this means engaging with other countries in the region and deterring potential threats emanating from the region that might threaten the U.S. homeland. ${ }^{48}$ But, just as important, it also means protecting U.S. territory in the Pacific, such as the states of Hawaii and Alaska, the U.S. territories of Guam, the Commonwealth of the Northern Mariana Islands, and American Samoa. Defense support to civil authorities of these homeland areas is a key mission for USPACOM through Joint Task Force-Homeland Defense (JTF-HD). ${ }^{49}$

Retaining and strengthening the United States' ability to shape the global environment. Being able to shape the environment in the Asia-Pacific region is also a U.S. national objective. This entails a number of approaches: (1) by providing security cooperation with allies and partners; (2) by working with regional forums such as ASEAN to build trust; (3) by preventing misperceptions and fostering cooperation; (4) by engaging with senior military and civilian leaders around the region; (5) by having sufficient permanent and rotational presence and capabilities to deter threats and reassure allies and partners; and (6) by communicating U.S. intent in a clear and consistent manner. ${ }^{50}$

The United States military obviously has a direct role in promoting and protecting U.S. economic prosperity, and nowhere is this more important than in the AsiaPacific region. U.S. forces help protect common access to the sea, air, space, and cyber domains to ensure the "free flow of commerce and economic development." These forces also help ensure the stability of the region, which is needed for economic well-being, through deterring coercion, responding to disasters, and

${ }^{47}$ United States Pacific Command, USPACOM Strategy, (2013); Ashton B. Carter, "The U.S. Strategic Rebalance to Asia: A Defense Perspective," (2013); and "Remarks by Tom Donilon, National Security Advisor to the President: 'The United States and the Asia-Pacific in 2013'” (2013).

48 "Remarks by Tom Donilon, National Security Advisor to the President: 'The United States and the Asia-Pacific in 2013'” (2013).

${ }^{49}$ JTF-HD is USPACOM's executive agent for homeland defense and falls under USARPAC. See Association of the United States Army, The U.S. Army in the Pacific: Assuring Security and Stability, Torchbearer National Security Report, April, 2013, p. 27; and United States Pacific Command, USPACOM Strategy (2013).

${ }^{50}$ United States Pacific Command, USPACOM Strategy (2013).

${ }^{51}$ Ibid. 
building relationships. ${ }^{52}$ They also engage with allies, partners, and emerging powers such as China. ${ }^{53}$

Overall, U.S. armed forces play an important deterrence role in the region, assist allies if they are attacked, protect the homeland, and counter terrorist and other nontraditional security threats. Yet, achieving regional stability and ensuring economic prosperity rests very heavily on the ability to successfully engage the region. Ways in which U.S. military engagement serves to support national objectives in the region include the following:

- Strengthen and update alliances. U.S. alliances are "the foundation of United States' regional, and global security." ${ }_{54}$ The alliances with Australia, Japan, South Korea, the Philippines, and Thailand are central to U.S. efforts to maintain security and stability in the region. Alliances need to be maintained, and allies in Asia need to be reassured of America's commitment to mutual defense. ${ }^{55}$ The region is dynamic, and allies have shifting perceptions of their national security needs. Continuous, deep engagement with our allies is essential in order for all parties to have a deeper understanding of the others' needs, priorities, and concerns as these relationships evolve. Operational engagement and capacity building through activities such as joint exercises and training can help increase allies' interoperability to deal with future crises. Interactions between the various military operators and administrators-such as professional military exchanges, dialogues, and educational exchanges-can create a greater understanding of each partner's unique concerns and interests. Military-to-military contact of all kinds can reinforce trust and communication among allies.

- Cultivate new and emerging partnerships. U.S. alliances alone are not adequate to maintain peace and stability in the Asia-Pacific region or in the world. $^{56}$ The reliance on building coalitions-both short term and long term-

\footnotetext{
${ }^{52}$ Ibid.

${ }^{53}$ Ibid.

${ }^{54} 2010$ National Security Strategy, p. 41.

${ }_{55} 2010$ Quadrennial Defense Review, p. 66; "Partnering in the Pacific Theater," p. 7; Kurt Campbell (U.S. Assistant Secretary of State for East Asian and Pacific Affairs), "U.S. Engagement in Asia," public lecture, Chulalongkorn University, Bangkok, Thailand, October 10, 2011, last accessed February 20, 2013, at http://bangkok.usembassy.gov/101011_us_engagement_in_asia. html.

${ }^{56} 2010$ U.S. National Security Strategy, pp. 11, 23, 43; 2012 Defense Strategic Guidance, p. 2; 2010 Quadrennial Defense Review, p. 2; 2011 National Military Strategy, p. 1; Thomas Donilon, "President Obama's Asia Policy \& Upcoming Trip to Asia, Remarks by National Security Advisor Tom Donilon," November 15, 2012, last accessed August 17, 2013, at http://www.whitehouse.gov/the-press-office/2012/11/15/remarks-national-security-advisor-
} 
is becoming an increasingly important aspect of U.S. policy in the region. The need to cultivate new partnerships is particularly relevant in Asia, where intraand extra-regional security relationships are expanding and evolving rapidly. ${ }^{57}$ Working with new and emerging partners can also increase their integration in, and support for, the current international order and principles of international law, as well as enhance collective security and burden-sharing. ${ }^{58}$ For example, military engagement with Burma, still in its initial stages, can help play a positive role in encouraging the country to be a more responsible member of the international community. Cultivating better military ties with Vietnam enhances Washington's ability to work with Hanoi on security issues of mutual concern.

- Engage rising powers. Building relationships with India and China provides the opportunity to manage changes in the regional and global power structure and help maintain stability and respect for international rules. Military-tomilitary engagement creates opportunities to develop the habits of cooperation with these rising powers, which can lead to more effective coordination in responding to non-traditional and other threats to stability. At a minimum, military engagement can potentially mitigate mutual suspicions. ${ }^{59}$

- Deter aggression. Engagement with regional partners may help deter a potential aggressor from taking harmful action, by improving the military capability of partner nations to defend themselves, operate with U.S. military forces, and support a U.S. forward presence. Such engagement also signals U.S. willingness to support an ally or partner. U.S. engagement activities with the South Korean military, for instance, play a critical role in deterring North Korea.

- Enhance the capacity and capabilities of our partners to address challenges on their own. Building capacity allows for greater burden-sharing in maintaining a stable international order. Greater capacity enables countries in the region to take on a greater share of securing their own security needs. More-capable allies and partners can also contribute to combined operations in support of regional and global security. For example, engagement can enhance the South Korean military's ability to contribute to regional security in

tom-donilon-prepared-delivery; and Hillary Rodham Clinton, “America's Pacific Century," Foreign Policy magazine, November 2011, last accessed February 25, 2013, at http://www.foreignpolicy.com/articles/2011/10/11/americas_pacific_century.

572011 National Military Strategy, p. 13.

${ }^{58}$ Clinton, “America’s Pacific Century” (2011).

${ }^{59}$ Interviews with Chinese think tank analysts, 2009, 2011, and 2012. 
Southeast Asia, or the Mongolian and Vietnamese armies' abilities to contribute to peacekeeping operations. ${ }^{60}$

- Improve U.S. military capabilities and readiness. Engagement with regional partners can also help the U.S. military improve its own capabilities and thus be better prepared to deal with a wide range of contingencies. Engagement in the region allows the U.S. military to develop and practice its ability to conduct combined operations with forces as diverse in capabilities as those from Australia, Japan, Thailand, Vietnam, Singapore, and the Philippines. Such interactions not only enhance the ability to work with those militaries during a contingency but also contribute to the ability of U.S. military forces to work with countries that have differing capabilities and differing security needs. Furthermore, the Asia-Pacific region offers a wide variety of climates and physical terrain for the U.S. Army to train and operate in. For example, engagement with Southeast Asian countries offers multiple opportunities to conduct jungle warfare training that would otherwise be unavailable or very limited for Army units located in Hawaii and elsewhere in the United States. ${ }^{61}$

- Maintain, gain, or enhance access. The security and prosperity of the United States and of the world rest on freedom of access by all to the global commons across all domains-sea, air, space, and cyber. ${ }^{62}$ The U.S. military has a prominent role to play in engaging with other countries to ensure access. If it has good interoperability with a foreign country's military, that country will be better able to work with the United States if the U.S. is seeking access to a theater (e.g., by providing logistics support). Engagement between militaries can also help establish precedents, so that when the United States seeks access in a crisis, the request is not without prior foundation. Military engagement with countries such as Japan, the Philippines, Singapore, Australia, and Vietnam can greatly enhance potential access to critical ports and airfields when the United States needs to flow forces into the region in response to a contingency.

- Foster or enhance cooperative efforts on humanitarian assistance and disaster relief (HA/DR) and other major transnational security concerns. Natural disasters are the most likely contingency that the U.S. military will be

\footnotetext{
${ }^{60}$ Interviews with U.S. Army officials, 2013; interviews with ROK government think tank analysts, 2013.

${ }^{61}$ Interviews with U.S. Army officials, 2013.

622012 Defense Strategic Guidance, p. 3; 2010 National Security Strategy, pp. 49-50; Michele Flournoy and Shawn Brimley, "The Contested Commons," Proceedings Magazine 135, 7 (Jul 2009), last accessed February 25, 2013, at http://www.usni.org/magazines/proceedings/200907/contested-commons.
} 
called upon to respond to in the Asia-Pacific region. ${ }^{63}$ In 2012 alone, natural disasters affected some 75 million people in China, the Philippines, Bangladesh, India, North Korea, Sri Lanka, Japan, Thailand, Burma, and Vietnam. ${ }^{64}$ The U.S. military needs to be able to prepare for, and carry out, cooperative responses with regional governments and non-governmental organizations. Participating in cooperative efforts such as HA/DR can also enhance the United States' longer-term relationships with foreign nations by building trust and confidence through cooperative activities. ${ }^{65}$

\section{Implications for the U.S. Army}

There are some clear implications for the U.S. Army in terms of the likely demand for land power in support of U.S. national security objectives in the Asia-Pacific region. The Army needs to be able to do the following:

- Contribute to the ability of the United States to deter aggression in the region, and, if necessary, fight. One of the most important objectives of the United States in the region is to maintain peace and stability. Deterring potential aggression, such as that which might occur on the Korean Peninsula, or acts of coercion and intimidation, such as over disputed territories in the East and South China Seas, is an important aspect of achieving that objective. ${ }^{66}$ In the event that deterrence fails or the unpredictable occurs, the Army will need to be able to surge tailored force packages into and across the region.

- Contribute to the ability of the United States to maintain and strengthen its alliances in the region. At a minimum, this means that the Army will be called upon to continue contributing to maintaining the five treaty alliances through exercises and other forms of military-to-military engagement. It will also mean that the Army will continue to be called upon to help reassure U.S. allies of Washington's commitments through presence, exchanges, and public statements. The Army is likely to also be called upon to assist the U.S. interagency in strengthening and extending ties with allied security forces and reinforcing U.S. messaging directed towards those allies. As will be discussed

${ }^{63}$ Interviews with U.S. Army officials, 2012 and 2013.

${ }^{64}$ United Nations, Office for the Coordination of Humanitarian Affairs, "Humanitarian Snapshot: Natural Disasters in Asia-Pacifc-2012," last accessed September 4, 2013, at http://reliefweb.int/sites/reliefweb.int/files/resources/ROAP_Snapshot_disasters_2012.pdf.

${ }^{65} 2011$ National Military Strategy, p. 15.

${ }^{66}$ Interviews with U.S. Army officials, 2012 and 2013; interviews with USFK officials, 2013. 
later in this study, many U.S. and Asian interviewees see it as critical that the Army maintain its current commitments to the region by conducting engagement and activities aimed at reassuring allies and partners. ${ }^{67}$

- Continue to contribute to U.S. efforts to build a positive relationship with China. Official U.S. documents clearly define China as a country of special concern both for its importance as a potential partner of the United States and for its potential to harm U.S. interests. The Army has considerable potential for further engaging with the Chinese military and its ground-force-dominated leadership. For example, in 2013 the PLA sent 60 soldiers to participate in an exercise in Hawaii with USARPAC and the Hawaiian National Guard ${ }^{68}$ In 2015 U.S. and Chinese soldiers participated in a Disaster Management Exchange held on Hainan Island. ${ }^{69}$ The Army also engages with China through interactions with the institutional Army, including regular exchanges by HQDA and TRADOC. ${ }^{70}$ Some interviewees thought there might be further opportunities to engage with Chinese ground forces on non-traditional security issues. ${ }^{71}$

- Contribute to the ability of the United States to build and strengthen relationships with a wide range of new, emerging, and established partners in the region. The United States seeks to build and enhance existing relationships throughout the region. The Army may be called upon to assist in building and further developing relationships with countries such as India, Burma, Vietnam, and Malaysia, as well as enhancing relations with longstanding partners such as Singapore. These countries vary considerably in terms of the capabilities of their ground forces, their security concerns, and the types of engagement activities they are willing to participate in. Both the

\footnotetext{
${ }^{67}$ Interviews with U.S. Army officials, 2012 and 2013; interviews with USFK officials, 2013; interviews with Japanese military and civilian defense officials, 2013; interviews with South Korean government think tank analysts, 2013; and interviews with Philippine military officials, 2013.

68 The exercise also included the Army Corps of Engineers and the Federal Emergency Management Agency. See "China, US Armies To Begin Joint Disaster Exercise in Hawaii, First Time in Field Training," Washington Post online, November 11, 2013, http://www. washingtonpost.com/national/china-us-armies-to-begin-joint-disaster-exercise-in-hawaii-firsttime-with-field-training/2013/11/11/cfa5a5f0-4b14-11e3-bf60-c1ca136ae14a_story.html.

${ }^{69}$ Angela E. Kershner, "Disaster Management Exchange 2015 concludes in China," online, January 26, 2015, last accessed May 12, 2015, at http://www.army.mil/article/141698/ Disaster_Management_Exchange_2015_concludes_in_China/.

${ }^{70}$ Interviews with U.S. Army officials, 2013.

${ }^{71}$ Interviews with U.S. Army officials, 2012 and 2013.
} 
operational and the institutional armies need to be able to tailor engagement activities across the spectrum of partner capabilities and needs. ${ }^{72}$

- Contribute to the ability of the U.S. military to respond to a wide range of non-traditional security threats in the region, many of which are wholly or partly land based. Traditional security concerns are not the only threat to peace and stability to the region. In order to secure stability and prosperity in the region, the United States needs to be able to respond to a wide variety of non-traditional security threats to stability and/or economic well-being in the region. These threats include natural and man-made disasters, transnational crime, and terrorism. These non-traditional threats are widespread throughout the region and are land based, and therefore a potential task for the Army. The Army may be called upon to work with the U.S. interagency in responding to disasters, countering drugs and other criminal activities, or responding to terrorist threats to the U.S. homeland or allies. The Army will therefore need to be able to provide flexible responses to meet these varied contingencies.

- Continue to contribute to the ability of the U.S. military to build partner capacity in the region and encourage burden-sharing. An important part of U.S. national strategy is to help allies and partners help themselves. As many threats in the region relate to ground forces, the Army will continue to be called upon to help build partner capacity for the South Korean military to defend against a North Korean attack or contribute to international security in Southeast Asia. Other examples of the Army's ability to build partner capacity include training to deal with counterterrorism and improvised explosive devices, and to improve NCO professionalization, doctrinal development, and collection and analysis of lessons learned. ${ }^{73}$

- Contribute to the U.S. government's ability to shape and influence the region. Shaping reinforces efforts to maintain regional stability and prosperity as well as other U.S. interests such as access and reinforcement of adherence to international norms and values. The Army's wide range of capabilities and its ability to respond to a wide range of conventional and unconventional landbased threats provides the Army with both the means and the opportunities to interact with the region's land-based security forces in a wide range of activities that can be used to shape and influence countries across Northeast, Southeast, and South Asia, as well as in the South Pacific. ${ }^{74}$

\footnotetext{
${ }^{72}$ Interviews with U.S. Army officials, 2012 and 2013.

${ }^{73}$ Interviews with U.S. Army officials, 2013.

${ }^{74}$ Interviews with U.S. non-government subject matter experts, 2013; interviews with U.S. government officials, 2012 and 2013.
} 
- Carry out these tasks throughout the region. U.S. objectives stress the importance of the entire region: the Western Pacific, East Asia, Southeast Asia, and South Asia. U.S. economic and security interests are "inextricably linked" to all of these regions. ${ }^{75}$ The Army needs to be able to engage with, and operate in, almost every country in the region if called upon to do so. While emerging powers such as China and India, and allies such as Japan and Australia, are obviously priorities, no part of the Asia-Pacific can be excluded from the areas within which the Army may need to operate. In particular, the Army will need to think further about how best to maintain a credible presence in South and Southeast Asia. Further enhancement of its ability to coordinate and prioritize the actions and activities of USARPAC with those of the National Guard's State Partnership program, TRADOC, FORSCOM, and other U.S.-based commands will more fully leverage and optimize the Army's ability to engage throughout the region.

These, then, are the broad demands for the U.S. Army as part of the joint force and interagency in the region. Before discussing what they imply for Army capabilities, we need to assess the strategic landscape. The Asia-Pacific strategic landscape has distinctive features that present both opportunities and challenges for the Army's ability to do what needs to be done in Asia.

${ }^{75} 2012$ Defense Strategic Guidance. 


\section{Chapter 3: The Strategic Landscape of the Asia-Pacific Region}

When thinking about the role of the U.S. Army in the region and the capabilities it will likely need, it is important to consider not only U.S. national objectives but also the strategic landscape with respect to land power. U.S. national objectives define the broad demands for land power in the region; the strategic landscape delineates the threats that the Army needs to be prepared for and the context in which it will need to operate. The strategic landscape is more than just the sum of existing and potential security threats to which the Army may be called upon to respond. It also contains geographical, political, social, and other features which impact what the Army will need to do and how it will need to do those things.

In this chapter we will examine the strategic landscape in the Asia-Pacific region and assess the key components that are potentially important to the role of the U.S. Army. We will examine key persistent features and major ongoing changes within the region that are likely to affect the Army's ability to conduct operations, actions, and activities in the region, and we will identify key security threats to which the Army may be called upon to respond. Together, this and the previous chapter provide the basis for the analysis of what the Army will need to be able to do in the region if it is to support the joint force and interagency in securing U.S. national security objectives.

The chapter is organized into four sections:

- First, we examine five persistent features of the physical and human landscape that are assessed as being especially likely to affect the U.S. Army's ability to carry out operations, actions, and activities in the region.

- Second, we identify three major ongoing changes in the strategic landscape as being likely to have a significant impact on the role of the U.S. Army (and the rest of the U.S. military). These are: (1) the rise of China, India, and other countries in Asia; (2) changes in how key countries in the region assess their security concerns; and (3) changes in how countries view the role of the United States and its ability to sustain its commitments in the region.

- Third, we identify the most likely security threats that the U.S. Army may need to respond to as part of the joint force and/or interagency. These comprise a 
range of traditional and non-traditional security threats, including: a potential conflict on the Korean Peninsula; a potential conflict in an anti-access/area denial (A2/AD) environment; internal security threats, especially in South and Southeast Asia; terrorism; and natural disasters.

- Fourth, we conclude by discussing the implications of the strategic landscape for the U.S. Army.

\section{Five persistent features}

In this section, we discuss and analyze five persistent features of the strategic landscape that we assess as being of key importance to, and having an impact on, the U.S. Army:

- Distances to and within the Asia-Pacific theater

- Enduring historical legacies

- Domestic political factors across the region

- Differing capabilities and needs among allied and partner armies

- The wide range of cultures and languages.

We believe that these features are the most important ones for the U.S. Army to consider when thinking about its role in the Asia-Pacific.

\section{Distances}

Moving personnel and materiel into and within the Asia-Pacific theater. One of the most important challenges for the U.S. Army is that of distance and the problem of flowing troops and equipment into and across the region in a timely manner (see Figure $2 .^{76}$ Light forces such as airborne and light infantry units can move relatively quickly; heavier forces cannot. ${ }^{77}$ The rapidity of deployment can impact the Army's

\footnotetext{
${ }^{76}$ Many of the American military personnel and civilian subject matter experts interviewed for this study raised the challenge of distance as a critical concern for all services.

77 The need to maintain adequate lift for heavy forces was a major concern for many U.S. interviewees in the region. Interviews with U.S. Army officials, 2012; interviews with U.S. Marine officials, 2013; and interviews with USFK officials, 2013. See also, Joel Wuthnow, Tamara Hemphill, David Finkelstein, and Albert Willner, The U.S. Army in Asia: Opportunities and
} 
response for a contingency, its ability to move the desired amount of equipment for a given exercise, and its ability to materially sustain long-term operations. ${ }^{78}$ Furthermore, airports, deep-water ports and transportation infrastructure vary widely across Asia, potentially further complicating the movement, arrival, and onward integration of forces in a major contingency. ${ }^{79}$ Moreover, permanent overseas Army bases in the region are limited to South Korea and Japan. While the existing base structure is well suited for flowing forces to Northeast Asia, it is not well suited for flowing them to the rest of the region. ${ }^{80}$

Challenges: Report of Workshop of Experts, CNA Conference Proceedings DCP-2013-U-004995Final, August 2013.

${ }^{78}$ Interviews with U.S. Army officials, 2012 and 2013.

${ }^{79}$ Wuthnow et al., The U.S. Army in Asia: Opportunities and Challenges: Report of Workshop of Experts.

${ }^{80}$ See Lynn E. Davis et al., U.S. Military Presence Overseas: What Are the Strategic Choices? (2012). 
Figure 2. Distances from Hawaii

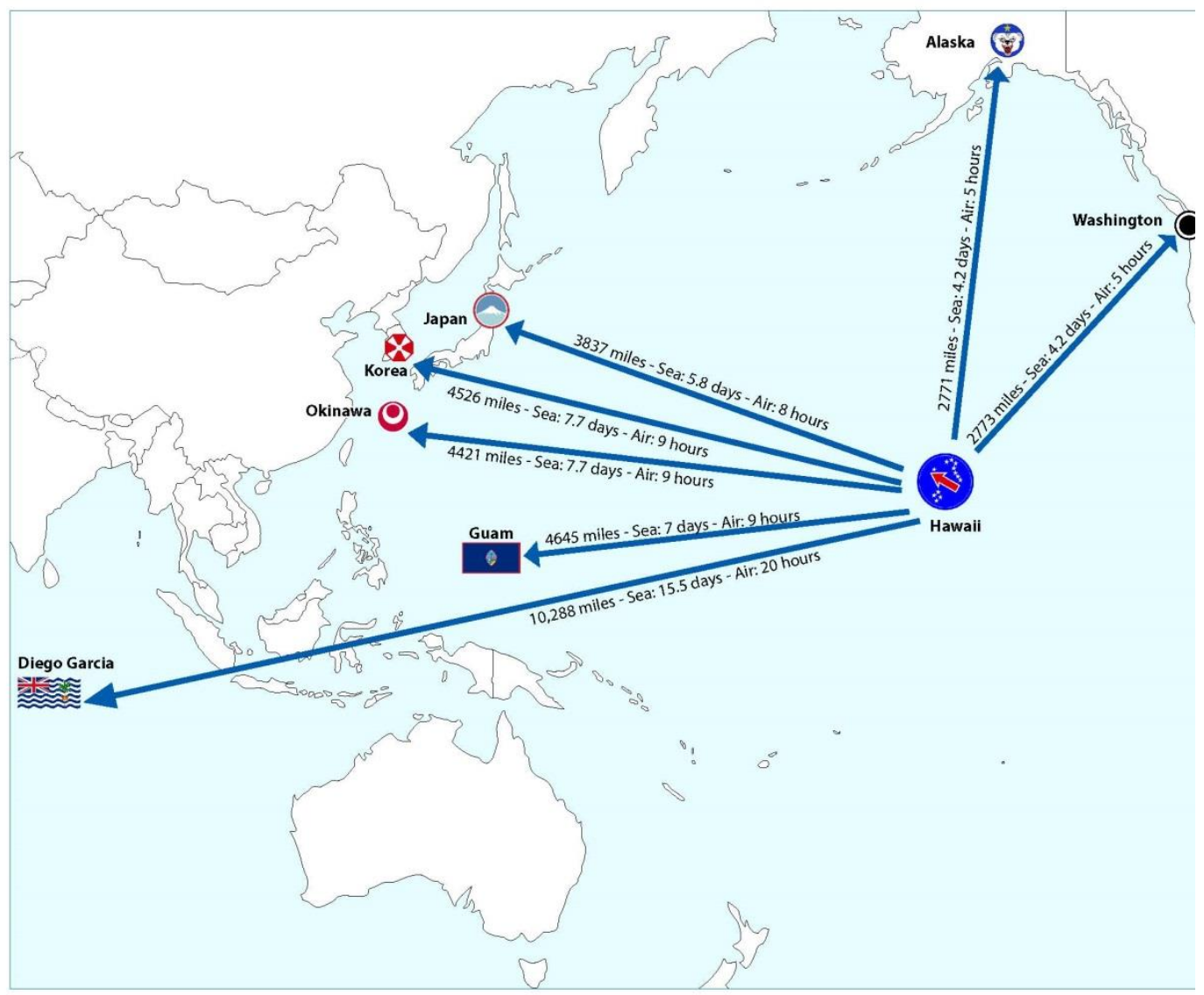

Source: Derived from Association of the United States Army, The U.S. Army in the Pacific: Assuring Security and Stability, Torchbearer National Security Report, April, 2013, p. 24.

The problem of moving troops and materiel across the Asia-Pacific region is unlikely to be mitigated by expanding the number of U.S. Army personnel permanently based in the region. U.S. military and civilian government personnel interviewed for this study were adamant that the U.S. government has little interest in establishing new overseas bases in Asia.$^{81}$ Similarly, Asian military officials and subject matter experts, while largely receptive to a U.S. military presence in the region, indicated that most

${ }^{81}$ Interviews with U.S. Army officials, 2012 and 2013. Also see TRADOC, "The U.S. Army Capstone Report," Pamphlet 525-3-0, 19 December 2012, p. iv. 
countries had little desire for large numbers of U.S. soldiers on their territory. ${ }^{82}$ Reasons given by these officials and experts included domestic political sensitivities to hosting large numbers of U.S. troops and concerns that such a move could alienate China. ${ }^{83}$

This suggests that in order to mitigate the challenges of moving forces into and across the region, the U.S. Army should consider (and in some cases is already doing) the following: ${ }^{84}$

- Expanding and updating pre-positioning of equipment so that it is available closer to where it will most likely be needed in the future, particularly for nontraditional contingencies and exercises. The U.S. Army will likely need to work with the other services and civilian agencies to lay the groundwork for new agreements as it is currently doing with regard to the Philippines. Beyond the Philippines, the Army should continue to examine the feasibility of expanding off-shore prepositioning, especially with regard to other countries in Southeast Asia and South Asia.

- Rethinking how best to assure presence, whether through greater rotational and temporary presence or through more efficiently sizing and training operational packages.

- Engaging with allies and partners to ensure permissible access to key ports and airfields for moving forces into and across the region in the event of a contingency.

- Ensuring sufficient access to air and sea lift in the region to move forces for both contingencies and exercises.

\section{Historical legacies}

Historical legacies continue to impact relations between countries in the region and the United States. For many countries throughout the Asia-Pacific region, the experiences of the colonial era, past conflicts, and long-standing rivalries continue to

\footnotetext{
${ }^{82}$ Interviews conducted with Vietnamese, Singaporean, Japanese, Korean, Philippine, and Thai military officials and think tank analysts, 2013. Interviews in Korea demonstrated that there was considerable concern about further U.S. military reductions, but no interest was expressed in seeing an increase in the number of U.S. forces permanently based in South Korea.

${ }^{83}$ Ibid.

84 Interviews with U.S. Army officials, 2012 and 2013; interviews with U.S. Marine officials, 2013. See also, Wuthnow et al., The U.S. Army in Asia: Opportunities and Challenges: Report of Workshop of Experts.
} 
shape national perceptions that can at times significantly impact relations between states in the region as well as those with the United States. For example, both the South Koreans and the Chinese still view Japan with considerable mistrust stemming from their experiences with Japanese imperialism at the end of the $19^{\text {th }}$ and the first half of the $20^{\text {th }}$ centuries. And in the Philippines, anti-colonial attitudes still exist in some sectors of the public, which continue to resist U.S. force presence. ${ }^{85}$ Similarly, historical memories help explain Vietnam's interest in maintaining an independent foreign policy and avoiding entanglements with either the United States or China. ${ }^{86}$

These legacies can complicate U.S. military interactions with regional actors and make it difficult to foster multilateral cooperation. For example, lingering distrust between South Korea and Japan can limit the ability of these countries to cooperate on security affairs as well as limit trilateral efforts between these two countries and the United States. ${ }^{87}$

If the U.S. Army is to be more effective in its engagement and strategic communications, planners and operators need to understand and anticipate how these perceptions might influence operations and activities. Interviews conducted for this study indicated that this need to do so was well appreciated by the Army's military and civilian officials with expertise in the region, though there was concern that the importance and impact of these historical legacies were not always as well understood as they should be. ${ }^{88}$

\section{Domestic politics}

Domestic politics are an important factor that the U.S. Army should consider when planning and engaging countries in the region. Some of the key countries of interest for the United States in the region-Australia, the Philippines, Thailand, South Korea, Japan, India, and Indonesia-are democracies or are democratizing with active and varied domestic constituencies. The state of domestic politics matters for the Army because it can have an impact on national security policy, receptivity to engagement activities with the Army, willingness to take on burden sharing,

\footnotetext{
${ }^{85}$ Interviews with Philippine military and civilian officials, 2013.

${ }^{86}$ Interviews with Vietnamese military officials, 2011, 2012, and 2013.

${ }^{87}$ Interviews with South Korean and Japanese civilian officials and think tank analysts, 2013. During the course of research for this project, several South Korean and Japanese interviewees brought up difficulties in advancing security cooperation between the two countries. Some South Korean interlocutors further noted that after reunification with North Korea, they saw Japan as a major potential future security challenge for Korea.

${ }^{88}$ Interviews with U.S. non-government subject matter experts, 2013; interviews with U.S. military and civilian officials, 2012 and 2013.
} 
sensitivities to a rising China (discussed later in this chapter), and defense priorities. As examples:

- Korean interviewees for this study noted that there were important differences between South Korean political parties regarding defense policy and especially the transfer of operational wartime control from the U.S. to the South Korean military. ${ }^{89}$ Several South Korean interviewees also stated that while the South Korean government recognized that it should take on more burden sharing on regional security issues, it was unlikely that Seoul would do more in the near term as domestic political considerations made it difficult to transfer more resources to defense. ${ }^{90}$

- Without being explicit, some Philippine interviewees indicated that the next Philippine presidential election - to be held in 2016-may lead to changes in that country's defense policy and relations with the United States. ${ }^{91}$ In Australia there is an active debate among some subject matter experts about how best to balance close security relations with the United States with growing economic ties with China; the outcome of that debate will have important implications for future U.S. planning assumptions. ${ }^{92}$

Understanding how domestic political issues can affect the way that audiences in a given country view U.S. operations, actions, and activities is critical to U.S. Army plans in the region. Army personnel, State Department personnel, and others with regional knowledge can help identify opportunities to shape messages with domestic political considerations in mind. As political trends can change rapidly, the Army must continue to have personnel actively engaged with important partner nations in order to stay informed and keep ahead of changes in domestic politics that can

\footnotetext{
${ }^{89}$ Interviews with South Korean government think tank analysts, 2013.

${ }^{90}$ Ibid.

${ }^{91}$ Interviews with Philippine military and civilian officials, 2013. The interviewees did not provide any information on what exactly might change; they only stated that personalities matter in Philippine politics and affect U.S.-Philippine relations.

${ }^{92}$ Over the past four years, much of the debate has been driven by the writings of Australian international relations specialist Hugh White. See, for example, Hugh White, "Power Shift: Australia's Future between Washington and Beijing," Quarterly Essay 39 (Collingwood, Victoria, Australia), September 2010. See also the rejoinders to White's essay in the subsequent issue, Quarterly Essay 40, by Gareth Evans, Michael Wesley, Bruce Grant, Robert D. Kaplan, and others, at www.quarterlyessay.com. See also Brendan Taylor, "China's Foreign Policy Aggressiveness," in Geremie Barme, ed., Red Rising, Red Eclipse, China Story Yearbook 2012 (Canberra: Australian Centre for China in the World, Australian National University, 2012); Albert Palazzo, "Australia and the Neglect of Defence: Echoes of 1942 in the Formulation of Present Security Policy," The Australian Army Journal (Winter 2012), pp. 15-32; and Hugh White, "Australia's Choice between the United States and China," Foreign Affairs, September 2013, http://www.foreignaffairs.com/articles/139902/hugh-white/australias-choice.
} 
affect the Army's activities and plans in the region. As it is unlikely that significantly more FAOs will be available for Asia in the near future, the Army should pursue ways to grow regional expertise among non-FAO officers. ${ }^{93}$

\section{Differences in capabilities}

The U.S. Army needs to be adaptable and able to tailor forces for engagements and operations that call for a wide range of regional capabilities. In order to support U.S. national security objectives in the region, the Army needs to be able to engage and operate with regional armies that vary considerably in capability.

U.S. Army personnel need to be able to plan engagement activities or conduct operations with countries which have a wide variety of regional capabilities. Countries such as Japan and Australia have highly effective governments and the economic capacity to field highly competent and modern armed forces that can work closely with the United States in a number of areas. ${ }^{94}$

Regional armies vary for several reasons: differences in economic development (the region contains highly developed, developing, and barely developed economies); different levels of defense spending; and widely differing security needs. The U.S. Army exercises and conducts operations with the Australian Army, which is relatively small but is very capable and has a wealth of experience at the global, regional, and local levels. TRADOC's International Army Programs Directorate has robust exchange programs with Australia, South Korea, and Japan, but opportunities for similar exchanges with other countries in the region are limited, in part because less developed countries in the region often cannot match what the Army brings to the table. The Army engages with the Indian Army, which has a very large but less modernized ground force that is focused on perceived threats from neighboring Pakistan and China. Other armies, such as that of the Philippines, have limited capabilities for internal defense or response to natural disasters, and even less ability to play an external role. ${ }^{95}$

\footnotetext{
${ }_{93}$ According to data provided in 2013 by the U.S. Army, there were over 200 Foreign Area Officers with Asian expertise-though it is important to note that not all area expertise is fungible across Asia. Furthermore, as reducing the number of billets for other regions of the globe, such as South America, might harm the ability of other Army Service Component Commands to engage with regional partners, it is unlikely that the number of Asian billets can be augmented anytime soon.

${ }^{94}$ Interviews with U.S. Army, U.S. Marine Corps, and USPACOM officials, 2013; interviews with Japanese military and civilian officials, 2013.

${ }^{95}$ Interviews with Philippine military and civilian officials, 2013. Although, in response to South China Sea concerns, Philippine external capabilities are likely to expand in the near term.
} 
Ideally, U.S. Army forces that operate and train in the Asia-Pacific region, as well as those that have an institutional interaction with the region, are cognizant of these different capabilities and tailor exchanges as appropriate to a wide range of demands. At the same time, Army institutions and organizations also need to understand what skills each engagement partner wants to learn from the United States and the best way for them to absorb U.S. capabilities and advice. ${ }^{96}$ The same holds true for contingencies. The capabilities that the Army might need to deploy in a disaster response in Japan will be very different from those needed for a similar emergency in the Philippines. Perhaps just as important, the Army needs to be receptive to what it can learn from these diverse militaries as well.

\section{Diversity of languages and cultures}

The U.S. Army will need to be able to operate across a wide range of languages and cultures in the Asia-Pacific region. While the point is fairly obvious, it still needs to be stressed that the Army will need the language skills and cultural knowledge to operate with diverse military and civilian forces across the region. U.S. national security objectives in the region emphasize the need to engage and build relationships. Furthermore, the Army will likely need to conduct combined and multinational operations with regional forces in humanitarian assistance and disaster relief operations, counterterrorism, and other contingencies. ${ }^{97}$

U.S. Army planners will need to have a good understanding of cultural sensitivities that might affect operations, activities, and relationship-building with armies in countries critical to the United States. The Army is undertaking a number of initiatives to develop and foster regional, cultural, and linguistic expertise among officers, career NCOs, and Army civilians-including the Strategic Broadening, Regional Affairs NCO, and Regional Broadening pilot programs. As these efforts progress, the next challenge for the Army will be to retain and promote personnel who have successfully completed these programs. ${ }^{98}$

The issues discussed in this section are persistent features of the region and, as such, are predictable. However, the Asia-Pacific is also a very dynamic region which is constantly evolving. Thus, as we discuss below, the U.S. Army must understand what is changing and how those changes might impact it in the future.

\footnotetext{
${ }^{96}$ Ibid.

${ }^{97}$ Interviews with U.S. Army officials, 2012 and 2013; interviews with U.S. Marine officials, 2013; interviews with South Korean and U.S. officials, 2013; interviews with Japanese government officials, 2013;. See also, Wuthnow et al., The U.S. Army in Asia: Opportunities and Challenges: Report of Workshop of Experts.

${ }^{98}$ Interviews with the U.S. Army officials, 2013.
} 


\section{Three major ongoing changes}

In addition to the enduring features just discussed, there are also three dynamic features of the strategic landscape that we assess as being of critical importance for the U.S. Army's role in the region. These include (1) the rise of China and others in the region, (2) the changes in how several regional countries are reassessing their security concerns, and (3) the changes in regional views of the United States.

\section{The rise of China and others}

An important and dynamic feature of the region is the rise of China and other powers in Asia. ${ }^{99}$ While China's rise has by far received the most attention, it is not the only actor in the region that is increasingly consequential militarily, politically, and economically. India is emerging as a major power in the region and is increasingly an actor of consequence globally. Countries such as Indonesia and South Korea also seek a more influential role in the region.

"In economic and political terms, China is unquestionably already a global power. With the possible exception of the United States, no other country is likely to have more influence on economic and strategic developments in the Asia-Pacific region."

— Department of the Prime Minister and Cabinet, Australia ${ }^{100}$

The rise of China. There is a rich and growing literature on China's rise, and a discussion of these writings would be a major study in itself. Some, including the National Intelligence Council, project that China's GDP will surpass that of the United States by 2030, if not earlier. ${ }^{101}$ China's economic and military rise is a factor in all

${ }^{99}$ Office of the Director of National Intelligence, National Intelligence Council, Global Trends 2030, last accessed November 16, 2013, at http://www.dni.gov/index.php/about/ organization/national-intelligence-council-global-trends (hereafter "National Intelligence Council, Global Trends 2030").

${ }^{100}$ Strong and Secure: A Strategy for Australia's National Security, Department of the Prime Minister and Cabinet, Australia, January 2013, pp. 29, 38; available at http://www.dpmc. gov.au/national_security/docs/national_security_strategy.pdf.

${ }^{101}$ National Intelligence Council, Global Trends 2030. See also Simon Rabinovitch, "China Forecast to Overtake US by 2016," Financial Times, March 22, 2013, http://www.ft.com/cms/s/0/0a3f5794-92b3-11e2-9593-00144feabdc0.html\#axzz2l77K3w00;

also Wayne M. Morrison, China's Economic Rise: History, Trends, Challenges, and Implications for the United States, Congressional Research Service Report RL33534, September 5, 2013. 
discussions of the Asia-Pacific region, and it is difficult to identify an issue or concern of the United States in the region, or globally, that is not affected in some way by China.

For the United States, and many of its allies and partners in the region, China's rise as a power presents two somewhat contradictory concerns. On the one hand, it is important for them to build a positive and cooperative relationship with China in order to reinforce regional stability, continue to develop economic ties, and address issues of mutual concern. On the other hand, China's growing military capabilities and uncertainty over its intent raise concerns in the United States about the potential for China to challenge the U.S. in the region and to pose security threats to some U.S. allies and partners.

The rise of China brings up several issues:

- China's growing importance to the global economy means that trade with China is increasingly central to the economic strategies of countries in their region. For many of America's partners and allies, China is now one of the most, if not the most important, trading partners. ${ }^{102}$ This means that economic relations are likely to be an increasingly critical factor in driving the strategic calculus of those countries. For example, while the government of South Korea sees its alliance with the United States as its most important relationship, it also perceives a need to build stronger relations with China because of its significance to the South Korean economy. ${ }^{103}$ Similarly, a major Australian government report stated that the "importance of deepening our relationship with China cannot be overstated." 104

- In addition to economic opportunities, the United States and some other countries also see political and security advantages to building a stronger relationship with China. As noted in the previous chapter, the United States sees the prospect of building a more cooperative relationship with China as part of building a stronger and more stable international system and addressing common problems. Some South Koreans see better relations with

\footnotetext{
${ }^{102}$ See, for example, Strong and Secure: A Strategy for Australia's National Security, Department of the Prime Minister and Cabinet, Australia, pp. 27, 29, and 38; and the National Intelligence Council, Global Trends 2030.

${ }^{103}$ Interviews with South Korean government officials and senior think tank analysts, 2013.

104 Strong and Secure: A Strategy for Australia's National Security, Department of the Prime Minister and Cabinet, Australia, January 2013, pp. 29, 39.
} 
China as a key to managing North Korea. ${ }^{105}$ Still other countries see benefits from cooperation with China on non-traditional security and other issues.

- At the same time, however, countries in the region are concerned about China's growing military power and intentions. As part of its rise, Beijing will likely continue to develop and expand its military capabilities. China has the second largest defense budget in the world, ${ }^{106}$ and that is likely to grow relative to that of the United States. China therefore is widely expected to increasingly be in a position to challenge the U.S. and others where it feels its interests are at stake. Concerns about China's intentions towards the region are, not surprisingly, widespread. ${ }^{107}$

For the U.S. Army, China's rise has at least three important implications:

- There will likely be increasing opportunities to expand military-to-military exchanges with China. China is potentially an important partner for the United States, especially as its armed forces remain dominated by the PLA ground force. The U.S. Army brings a wide range of capabilities (see next chapter) that can be used to engage China on, for example, non-traditional security issues such as terrorism and humanitarian assistance. A good example is the 2015 Disaster Management Exchange held on Hainan Island, which involved both U.S. and Chinese soldiers. ${ }^{108}$

- Some countries may be interested in greater engagement activities with the U.S. military, including the U.S. Army, as a hedge against China's rise. For example, several Japanese interviewees for this study expressed interest in seeing further military cooperation in what is already a very strong alliance, partly due to concerns over a rising China. ${ }^{109}$

\footnotetext{
${ }^{105}$ Interviews with South Korean think tank analysts, 2013; On Indonesia, see, for example, "Indonesia, China to Strengthen Defense Cooperation," The Jakarta Post, March 23, 2011, http://www.thejakartapost.com/news/2011/03/23/indonesia-china-strengthen-defensecooperation.html. On Thailand, see "Thailand-China to Push Forward Defense Cooperation," website of the Royal Thai Government, July 24, 2013, http://www.thaigov.go.th/en/newsroom/item/78741-thailand-china-to-push-forward-defense-cooperation.html.

${ }^{106}$ For more on China's defense budget, see Office of the Secretary of Defense, Annual Report to Congress: Military and Security Developments Involving the People's Republic of China, pp. 4546.

${ }^{107}$ Interviews with defense officials from India, Japan, the Philippines, South Korea, Singapore, and Vietnam, 2013.

${ }^{108}$ Kershner, “Disaster Management Exchange 2015 concludes in China,” January 26, 2015.

${ }^{109}$ Interviews with Japanese defense ministry officials, 2013.
} 
- Conversely, some countries may be reluctant to engage in some types of exercises with the U.S. military for fear of damaging their relations with China. Data for this study indicate that however much countries in the region appreciate the presence of U.S. military forces, such a presence should not be at the expense of heightened U.S.-China tensions, which, in turn, might harm economic concerns. ${ }^{110}$

The rise of others in Asia. In addition to the rise of China, several other power shifts in the region have the potential to impact the U.S. Army's efforts. For example:

- India is also a rising power and an international actor of consequence. Most of the data available indicate a wide expectation that India will continue to grow as an economic, political, and military actor in the region and beyond. ${ }^{111}$ In particular, India's "Look East" policy is likely to make New Delhi a more important factor in Southeast Asia as it continues to further develop political and military ties with ASEAN countries and participate in ASEAN-related forums. ${ }^{112}$ India is also seeking to further develop and enhance its security relationships with Japan and others. ${ }^{113}$ This suggests a potential for India to become more involved in multilateral engagement with the U.S. military, including the U.S. Army.

- Many South Korean subject matter experts and government officials see South Korea as a growing middle power that will have a greater role in regional and global affairs. ${ }^{114}$ In order to protect maritime trade routes, overseas investments, and their citizens abroad, it is likely to increase the role and capabilities of its naval forces as well as expand the range of its military-tomilitary relations. ${ }^{115}$ The extent to which it pursues these interests will depend largely on relations with North Korea and the willingness of some political parties to endorse a more outward oriented national security policy. ${ }^{116}$ This

110 Interviews with Singaporean government officials, 2012; interviews with Malaysian government officials, 2012.

${ }^{111}$ National Intelligence Council, Global Trends 2030, p. 15.

${ }^{112}$ Interviews with Indian military personnel and think tank analysts, 2013; interviews with U.S. Southeast Asian subject matter experts, 2013.

${ }^{113}$ Interviews with Japanese defense ministry officials and Indian government officials, 2013.

${ }^{114}$ Interviews with South Korean government think tank analysts, 2013. Similar observations were made by several U.S. subject matter experts at a CNA workshop on the U.S. Army in Asia, as noted in the transcripts for the CNA workshop report, Wuthnow et al., U.S. Army in Asia: Opportunities and Challenges: Report of Workshop of Experts.

${ }^{115}$ Interviews with South Korean government think tank analysts, 2013.

${ }^{116}$ Ibid. Interviews with South Korean government think tank analysts indicated that there was little prospect of a significant change in ROK approaches to defense prioritization as long as 
may lead to new opportunities for the U.S. and South Korean militaries to engage with each other outside the Peninsula and to a greater role for South Korea in terms of burden sharing.

- Indonesia is increasingly seen by some as a rising economic power and a regional leader in Southeast Asia. ${ }^{117}$ Therefore, engaging with Indonesian officials is likely to be an increasingly important part of U.S. military and Army efforts in building relationships with the Indonesian military. ${ }^{118}$

- Some analysts see ASEAN as being an increasingly important economic power. ${ }^{119}$ The growing economic performance of many of its members and the evolution of ASEAN-associated forums such as the ASEAN Defense Ministers' Meetings $(\mathrm{ADMM}+)$ is taken by some observers as an important change in power relations in the region. ${ }^{120}$ Thus, ASEAN may become more important in terms of U.S. Army engagement activities-especially multilateral security efforts such as responding to HA/DR and other non-traditional security concerns.

The rise of others in Asia has several important implications for the U.S. Army and its role in the region:

- In response to the rise of India, South Korea, Indonesia, and ASEAN, the operational commands in the theater and the institutional commands in the continental United States (CONUS) will likely need to revisit their engagement plans to ensure that shaping activities are adjusted accordingly.

- U.S. Army planners and operators will need a good understanding of the interplay between these rising powers and the impact on other countries, again underscoring the importance of efforts to grow and retain regional expertise.

the North Korean threat remained at current levels. Interviewees also noted that politicians on the left in South Korea tended to view South Korea as primarily a continental power, while those on the right were more interested in building up South Korea's status as a maritime power.

${ }^{117}$ National Intelligence Council, Global Trends 2030, p. 15. Also see transcripts, CNA Army Workshop, Wuthnow et al., U.S. Army in Asia: Opportunities and Challenges: Report of Workshop of Experts.

${ }^{118}$ Interviews with USPACOM officials, 2012 and 2013.

119 Interviews with U.S. non-government subject matter experts, 2013; and unpublished transcripts, CNA Army Workshop, Wuthnow et al., U.S. Army in Asia: Opportunities and Challenges: Report of Workshop of Experts.

${ }^{120}$ Ibid. 
- The U.S. Army should consider seeking more engagement opportunities that meet rising power interests in a way that is consistent with U.S. interests in the region.

\section{Ongoing changes in how several regional countries assess their security concerns}

There are ongoing shifts in how countries in the region think about their security needs and the role of land power in their overall national security strategies. The following are the most common themes that emerged from our research.

There is less concern about the likelihood of interstate land war. Few countries in the region perceive that there is a significant land-based threat from another state; India and South Korea are the major exceptions. For India, the principal threats are the potential for war with Pakistan and with China over their disputed border. Increasingly, the potential for a conflict with China is seen by many Indian military experts as the greater long-term threat. ${ }^{121}$ South Korea, of course, is still focused on the threat from North Korea. ${ }^{122}$ For most countries in the region, however, the primary security threats are maritime and/or land-based non-state security threats such as internal stability, terrorism, natural disasters, and trans-national crime.

Maritime disputes are growing as a principal concern. There is growing unease over maritime disputes as a potential threat. The nature of potential interstate conflict is moving from land to sea. For example:

- Japan is in the process of shifting a significant part of its focus from purely a defense of the home islands to protection of the Ryukyu Islands and its maritime claims in the East China Sea. ${ }^{123}$ Japan especially is increasingly focused on the potential threat that China poses to the disputed Senkaku/Diaoyu Islands, and is developing amphibious and island defense capabilities for its Ground Self-Defense Forces. ${ }^{124}$

- The Philippines perceives a major threat from China (and, to a lesser extent, from Vietnam and Malaysia, which also have maritime disputes with the

\footnotetext{
${ }^{121}$ Interviews with Indian military officials and think tank analysts, 2013.

${ }^{122}$ This, of course, does not mean that other interstate land wars involving the United States might not occur. The U.S. Army, as always, will need to maintain readiness for unexpected conflicts as well.

${ }^{123}$ Government of Japan, Ministry of Defense, Defense of Japan 2013; interviews with Japanese defense officials, 2013.

${ }^{124}$ Interviews with Japanese defense officials, 2013.
} 
Philippines) and is shifting its defense priorities to the maritime domain, especially the defense of its claims in the Spratlys. ${ }^{125}$ Several Philippine military and civilian experts noted that the Philippine military would increasingly turn its attention to addressing challenges in the maritime domain and that the Philippine Army would receive a lower priority in defense modernization efforts. ${ }^{126}$

- In South Korea, there is growing concern over maritime disputes with China and Japan, and a growing perception of the need to have a navy that can protect South Korean maritime trade and lines of communication. ${ }^{127}$ Some South Korean subject matter experts interviewed for this project argued that after unification, Korea's principal external threats would be maritime and not land based. ${ }^{128}$

- Vietnam, driven by its disputes with China over the status of the Paracel and Spratly Islands and maritime boundary issues, is increasingly focusing on the maritime domain as the principal source of external threat. In multiple interviews, Vietnamese government officials and military think-tank analysts consistently stated that China was seen not as a land threat to Vietnam but rather as a threat to Hanoi's access to resources in the South China Sea. ${ }^{129}$

- China is increasingly emphasizing the maritime domain as one of its principal security concerns. It is growing its maritime capabilities accordingly, which is raising concerns among many of its neighbors. ${ }^{130}$

Several countries of importance to the United States in the region perceive nontraditional security threats as an increasingly important concern. Despite the relative absence of external state-based land threats in the region, many countries do have major concerns about non-traditional challenges. This reflects a growing consensus in a number of countries that the most persistent security threats of the

\footnotetext{
${ }^{125}$ Interview with Philippine senior military official, 2013.

${ }^{126}$ Interviews with Philippine senior military and civilian officials, 2013.

${ }^{127}$ Interviews with South Korean government think tank analysts, 2013. While current South Korean defense reform plans call for a smaller army and marine corps by 2020, the South Korean government does not intend to reduce the number of personnel assigned to the air force and navy. See also South Korea's Ministry of Defense website, "Korean Defense Reform," http://www.mnd.go.kr/mbshome/mbs/mnd_eng/subview.jsp?id=mnd_eng_021100000000.

${ }^{128}$ Interviews with South Korean government think tank analysts, 2013. Interlocutors stated that Japan and China posed equal threats to Korean maritime interests, but did not see China as a land threat post-unification.

${ }^{129}$ Interviews with Vietnamese think tank analysts, 2012 and 2013.

${ }^{130}$ See, for example, Defense of Japan 2013.
} 
future may come not from other states, but rather from non-state actors such as terrorists, pirates, smugglers and traffickers, pandemic disease, natural disasters, and climate change. For example:

- Vietnam's 2009 defense white paper listed piracy, "illegal trafficking of weapons and drugs," "organized transnational crimes," and "illegal migration and immigration" among key non-traditional security challenges. It also pointed to the role of border guards in "combating crimes such as trans-border smuggling, illegal migration, women, children, and drug trafficking, and so on...."131

- South Korea's 2010 defense white paper noted: "Communicable diseases, including SARS and the H1N1 virus, are spreading around the world. At the same time, mega-class natural disasters...have also emerged as new security threats. To meet these challenges requires joint international efforts." ${ }^{132}$

- Interviewees from the Philippine, Chinese, Vietnamese, and Japanese militaries all see natural disasters as a severe problem for the region and one in which ground forces are more likely to be used in the future. ${ }^{133}$ In the Philippines, for instance, the ground force is expected to take on a significant role in natural disaster response, and the country has set up a Natural Disaster Risk Management Center. ${ }^{134}$

- A 2009 study by India's Institute for Defence Studies and Analyses declared that "India's neighborhood is in turmoil," and detailed problems of internal stability in several neighboring countries that were affecting India's domestic security. In particular, the report emphasized the fragility of the Pakistani government, which the authors argued was exacerbating the problem of terrorists operating across the India-Pakistan border. ${ }^{135}$ Several Indian

\footnotetext{
${ }^{131}$ Vietnam National Defense, Ministry of National Defense, Vietnam, December 2009, pp. 18, 26, available at: http://merln.ndu.edu/whitepapers/Vietnam2009.pdf.

1322010 Defense White Paper, Ministry of National Defense, Republic of Korea, December 31, 2010, p. 10, available at: http://www.nti.org/media/pdfs/2010WhitePaperAll_eng.pdf?_=134 $\underline{0662780 .}$.

133 Interviews with Chinese think tank analysts, 2012; interviews with Philippine military officials, 2013; interviews with Vietnamese military officials, 2013; and interviews with Japanese defense officials, 2013.

${ }^{134}$ Interviews with senior Philippine military officials, 2013.

135 “Brief of India's Neighborhood," Institute for Defence Studies and Analyses, May 28, 2009, available at: http://idsa.in/system/files/indianeighbourhood.pdf.
} 
interviewees for this study emphasized the importance of further developing the Indian Army's ability to respond to international terrorism. ${ }^{136}$

All these issues provide windows of opportunity for the U.S. Army in terms of engagement. While the Army will still have to prepare for traditional warfighting-for example, on the Korean Peninsula-non-traditional threats, as described above, are much more common, and, given the increasing focus of Asia-Pacific countries on these threats, the demand signal for countering them will likely increase. ${ }^{137}$

In some countries, there is an ongoing debate about the future role of their ground forces. Changing threat perceptions are generating debates about the future role of ground forces in several countries of interest to the United States, including Japan, South Korea, the Philippines, and Vietnam. ${ }^{138}$ The debates include: (1) whether to reduce the role of ground forces and transfer resources to air and naval forces; (2) whether to develop a maritime role for army units, such as land-based anti-ship missiles and/or amphibious capabilities; and (3) whether to participate more fully in peacekeeping and other contributions to regional and global security.

For example:

- Some in Vietnam and Japan are looking at developing their own A2/AD capabilities, including a ground force role of operating shore-based anti-ship missiles, to counter what they see as an increasingly aggressive China. ${ }^{139}$

- Interviews with Japanese defense officials indicate that there was a possibility that the Ground Self-Defense Force would be reduced in order to free up resources for the maritime and air self-defense forces. ${ }^{140}$

- The Philippine military is making the ground forces a lower priority. It is also transitioning its army out of internal security roles and planning to give the

\footnotetext{
${ }^{136}$ Interviews with Indian military officials and think tank analysts, 2013.

${ }^{137}$ Interviews with U.S. non-government subject matter experts, 2013; interviews with USPACOM officials, 2012 and 2013; interviews with Philippine military officials, 2013; and interviews with Japanese defense officials, 2013.

${ }^{138}$ Interviews with South Korea, Vietnam, Japan, Singapore, and the Philippines military and civilian officials, 2013.

${ }^{139}$ Defense of Japan 2013; interviews with Japanese defense officials, 2013; and interviews with Vietnamese think tank analysts, 2011.

${ }^{140}$ Interviews with Japanese defense officials, 2013. Japanese interlocutors were divided on the likelihood that this would happen. Two Japanese defense officials argued that the Ground SelfDefense Force had enough political influence to resist any efforts to make significant personnel reductions. Others thought that it was inevitable that the ground forces would shrink.
} 
Philippine ground forces a larger role in responding to natural disastersthereby changing the army's missions and the capabilities it needs. ${ }^{141}$

- Some countries, such as Mongolia, Vietnam, and the Philippines, are interested in either developing or enhancing their ground forces' ability to participate in peacekeeping operations (PKO). Often, participating in PKO is viewed as a way of proving a country's intention to be a "responsible contributor to global security," as one South Korean security expert put it, and-for less-capable militaries - a way to build military capacity. ${ }^{142}$

Implications for the U.S. Army: While it remains to be seen how much regional ground force roles will actually change, these debates strongly suggest that there will be changes in the demand signal for what skills and capabilities many regional armies will want to develop. These changes will have important implications for the U.S. Army. For example:

- A growing focus on non-traditional security challenges will likely lead to a higher demand signal for the U.S. Army to engage with regional militaries on these security issues. In particular, the Army is likely to see greater interest by Asia-Pacific countries in exercises and other activities that focus on counterterror, HA/DR, pandemic response, and transnational crime. ${ }^{143}$

- The U.S. Army is likely to also see increased demand for engagement activities that help countries in the region contribute to global security, such as training for PKO missions.

- As some countries begin to focus more on maritime concerns, they may become more interested in engagements with the U.S. Navy and/or U.S. Marine Corps, as the U.S. Army does not have the appropriate expertise and capabilities. For example, Japan's interest in building ground force expertise in island defense and amphibious operations means that the Ground Self-Defense Force will likely expand its engagement with the U.S. Marines. ${ }^{144}$ Relationships established by the Army can serve an important role in facilitating engagement with the other U.S. services.

\footnotetext{
${ }^{141}$ Interviews with Philippine military and civilian officials, 2013.

${ }^{142}$ Interviews with South Korean think tank analysts, 2013.

${ }^{143}$ Interviews with Indian, Philippine, Japanese, and U.S. military officials, 2013.

144“Japan's Amphibious Buildup,” USNI News, October 9, 2013, last accessed October 15, 2013, at http://news.usni.org/2013/10/09/japans-amphibious-buildup. Other regional armies that have or are developing amphibious capabilities include India, Australia, and New Zealand.
} 
- As regional countries shift resources to meet changing security concerns, they may become less able to maintain the levels and types of engagement activity that they currently have with the U.S. Army.

\section{Changing views of the United States}

Analysis for this study indicates that there are three ongoing and contradictory trends in regional views of the United States. First, many countries in the region regard the United States as a stabilizing presence and generally welcome the Obama administration's plans for the rebalance to Asia, particularly in light of China's rise. Second, there are significant concerns about the ability of the United States to sustain the rebalance. Third, some allies and partners are concerned about the level of U.S. commitment to its friends and allies.

Many countries in the region see U.S. presence as contributing to regional stability and welcome the rebalance. The majority of regional voices tend to be positive toward U.S. presence in the region, noting that it helps deter conflict and maintain strategic balance-and the concerns of some countries about the rise of China tend to reinforce this perception. ${ }^{145}$ Because of this perception, most countries in the region also express support for the rebalance. For example:

- Australia's defense white paper pointed out that the rebalance "provides opportunities for deeper bilateral and multilateral political, economic, diplomatic, and military cooperation with the United States." The document also affirmed that, through the rebalance, the United States is "shifting its strategic posture to support a peaceful region where sovereign states can enjoy continued security and prosperity." ${ }^{146}$ Australian public opinion has also been supportive of aspects of the rebalance. For instance, in a 2012 survey, 74 percent of Australians favored the rotational deployment of U.S. Marines to northern Australia. ${ }^{147}$

- A senior Japanese Self-Defense Forces officer argued that U.S.-Japan relations have improved under the administration of Prime Minister Shinzo Abe, and that Japan recognizes the U.S. Defense Strategic Guidance-a key document

\footnotetext{
${ }^{145}$ Ibid.

${ }^{146}$ Defence White Paper 2013, Department of Defence, Australia, May 3, 2013, p. 10, available at: http://www.defence.gov.au/whitepaper2013/docs/WP_2013_web.pdf.

147 Lowy Institute Poll 2012, “Strong Support for U.S. Marines in Australia," available at: http://www.lowyinstitute.org/news-and-media/hot-topic/lowy-poll-2012-strong-support-usmarines-australia.
} 
that explains the Department of Defense's role in the rebalance-as "an opportunity to strengthen relations with the United States." ${ }^{148}$

- Current and emerging partners have also occasionally registered support for the U.S. rebalance. For instance, Singapore's former prime minister Goh Chok Tong said that, despite China's worries about the U.S. strategy of rebalancing to the region, "the fact is that the U.S. has long played a major role in East Asia and contributed to the stability that has led to more than 30 years of growth and prosperity."

At the same time, however, data for this study also indicate that there are important concerns regarding the ability of the United States to sustain the rebalance in light of U.S. fiscal challenges. Therefore, many of the states that welcome the rebalance have significant doubts about its sustainability.

For example:

- A noted Indian security expert wrote that there is "much residual skepticism" in India about the United States' ability to carry out its rebalancing strategy. As this expert explained, "The financial crisis in the United States, questions about the speed of the country's economic recovery, and the uncertain dynamics of American domestic politics all raise legitimate questions about the sustainability of the pivot." ${ }^{149}$

- Multiple interviews indicated that sequestration and potential cuts to U.S. military strength, including talk of cuts to the Army, were interpreted as being evidence that the United States might reduce its commitments to the region and that the rebalance was not sustainable. ${ }^{150}$ One Singaporean official told the authors that every time the U.S. military warns Congress about the impact of sequestration, regional confidence in the United States goes down. ${ }^{151}$

\footnotetext{
${ }^{148}$ Interviews with Japanese defense officials, 2013.

${ }^{149}$ C. Raja Mohan, “India: Between 'Strategic Autonomy' and 'Geopolitical Opportunity,'” Asia Policy no. 15 (January 2013), pp. 21-25, available at http://www.nbr.org/publications/ asia_policy/free/07152013/AP15_B_AsiaBalanceRT.pdf.

${ }^{150}$ Interviews with Japanese, Korean, Indian, Singaporean, and Philippine officials and think tank analysts, 2013.

${ }^{151}$ Interview with Singaporean government official, 2013.
} 
- Some interviewees for this study have expressed concerns that the United States might be distracted by events in the Middle East and divert resources to that area and away from the rebalance to the Asia-Pacific region. ${ }^{152}$

Some allies and partners also have concerns about what shape U.S. commitments will take. There are worries about the level of U.S. commitment to its allies. For example, some of the South Korean officials and think tank analysts interviewed for this study expressed anxiety, saying that the U.S. rebalance was moving resources toward Southeast Asia at the expense of its commitments in Northeast Asia. ${ }^{153}$ Some Japanese officials expressed concern over what they perceived as an initial lack of support from the United States in Japan's current dispute with China over the Senkakus. ${ }^{154}$

\section{Implications for the U.S. Army}

- Positive views of the rebalance and of the U.S. contribution to regional stability suggest that there may be expanded opportunities for the U.S. Army to engage with countries in the region and further enhance relationships that support U.S. national objectives. For example, enhanced engagement may help further U.S. access to the region in a crisis, or help encourage burden sharing with allies and partners.

- Any future reductions of the U.S. Army in Asia may be perceived by some in the region as lowering U.S. commitment to the region and will need to be managed carefully..$^{155}$

- Given the extent of concerns over the sustainability of the rebalance and the level of commitment, it will be important to continue to reassure allies and partners. The U.S. Army may wish to consider how best to leverage current and future engagement activities to reinforce whole-of-government strategic messaging aimed at reassuring countries in the region and stressing U.S. commitment. It will also be important to revisit how the Army coordinates strategic messaging and engagement activities across HQDA, the Army National Guard, TRADOC, FORSCOM, and other CONUS-based commands, and how these activities are synchronized with efforts by USPACOM and USARPAC.

\footnotetext{
${ }^{152}$ Interviews with Japanese, South Korean, and Singaporean military and civilian officials and think tank analysts, 2013.

${ }^{153}$ Interviews with South Korean officials and government think tank analysts, 2013.

${ }^{154}$ Ibid.

${ }^{155}$ Ibid.; interviews with Japanese defense officials, 2013.
} 


\section{A mix of traditional and non-traditional security threats}

A range of traditional and non-traditional security threats will likely continue to drive U.S. Army efforts in the region. These threats range from long-standing concerns-such as the potential for major combat operations on the Korean Peninsula-to relatively new ones tied to climate change and natural disasters. ${ }^{156}$ Certain likely scenarios deserve priority attention.

\section{Potential crisis on the Korean peninsula}

A major takeaway for this study is that a Korean crisis remains one of the greatest, if not the greatest, threats to U.S. interests in the region. ${ }^{157}$ Any conflict on the Korean Peninsula, whether from a deliberate attack by North Korea, a provocation by North Korea that leads to escalation to a limited or general conflict, or a violent collapse of the regime in Pyongyang, would have an extremely high impact on U.S. and regional interests as the North's nuclear weapons might be in play and both Seoul and Pyongyang would see a conflict as potentially posing an existential threat. ${ }^{158}$

\footnotetext{
${ }^{156}$ USPACOM has identified both a contingency on the Korean Peninsula and a natural disaster related to climate change as major threats to U.S. interests in the region. See Admiral Locklear's testimony before Congress, "The Posture of the U.S. Pacific Command and U.S. Strategic Command," transcript from the House Armed Services Committee, March 5, 2013, para. 54, http://www.pacom.mil/commander/statementstestimony/20130305-hasc-uspacom-posturetranscript.shtml.

157 Office of the Director of National Intelligence, Remarks as delivered by James R. Clapper, Director of National Intelligence, "Worldwide Threat Assessment," delivered to the House Permanent Select Committee on Intelligence, April 11, 2013; interviews with USPACOM officials, 2012; and transcripts, CNA Army workshop report, Wuthnow et al., U.S. Army in Asia: Opportunities and Challenges: Report of Workshop of Experts.

${ }^{158}$ For more on possible Korean conflict scenarios, see Ken E. Gause, North Korean Calculus in the Maritime Environment: Covert versus Overt Provocations, CNA Occasional Paper COP-2013U-005210, July 2013; Ken E. Gause, North Korea After Kim Chong-il: Leadership Dynamics and Potential Crisis Scenarios, CNA Information Memorandum D0026119.A1, November 2011; Ken E. Gause, "Can The North Korean Regime Survive Kim Chong-Il?" Korean Journal of Defense Analysis 20, no. 2 (June 2008); Ferial Ara Saeed and James J. Przystup, Korean Futures: Challenges to US Diplomacy of North Korean Regime Collapse, Institute for National Strategic
} 
It is also the most likely potential conflict in the region that might require the U.S. Army to engage in major ground combat operations in the near future. ${ }^{159}$ While the United States and South Korea have successfully managed the potential threat of a Korean crisis for over 60 years, the risks of such a conflict remain high.

Several points bear emphasizing:

- First, both the South and North Korean regimes would see their national-level survival as being at stake. Seoul, the South Korean capital and home to half the country's population, is within artillery range of North Korean forces, meaning that some 25 million citizens of a U.S. treaty ally, therefore, are at high risk in the event of a conflict. The U.S. response in a crisis or its aftermath would have significant consequences for the security of a U.S. treaty ally and the credibility of U.S. commitments in Asia and globally. For North Korea, a crisis could lead to the end of the regime, and it is unclear how far North Korean elites might be willing to go in order to ensure their survival. Some subject matter experts have suggested that there could be a prolonged period of resistance by old regime elements far in excess of what was seen in Iraq. ${ }^{160}$

Studies, Strategic Perspectives no. 7, September 2011; Armin Rosen, "The Long History of (Wrongly) Predicting North Korea's Collapse,” The Atlantic, 6 August 2012; Bruce Bennett and Jennifer Lind, "The Collapse of North Korea: Military Missions and Requirements," International Security 2, issue 36 (Fall 2011), pp. 84-119; Bruce E. Bechtol, Jr., "Planning for the Future: Conditions of Combined ROK-U.S. Military Intervention in Potential DPRK Contingencies," The Korean Journal of Defense Analysis 24, no. 4 (December 2012); Paul B. Stares et al., Preparing for Sudden Change in North Korea (New York: Council on Foreign Relations, Special Report No. 42, January 2009); Michael E. O'Hanlon and Mike M. Mochizuki, Crisis on the Korean Peninsula: A War like No Other (New York: McGraw Hill, 2003); and Michael E. O'Hanlon, "North Korea Collapse Scenarios," Brookings Northeast Asia Commentary, June 2009, at http://www.brookings.edu/research/opinions/2009/06/north-korea-ohanlon. Some U.S. interviewees see a North Korean collapse scenario as increasingly becoming the likeliest scenario going forward and see an increasing overlap between a war scenario and a collapse scenario for military planning purposes. Interviews with U.S. military officials, 2013. Also, TRADOC, The U.S. Army Capstone Concept, TRADOC PAM 525-3-0, 19 December 2012, p. 7, states that the chance of a renewed Korean war is remote but that there is a distinct potential for an implosion of the regime. A study by CSIS focuses heavily on the prospects of a North Korean collapse as the more likely security trend. See Nathan Freier et al., Beyond the Last War: Balancing Ground Forces and Future Challenges Risk in USCENTCOM and USPACOM, April 2013.

159 There is, of course, always the possibility that the United States will be involved in major ground combat operations in a conflict that was not anticipated. As many U.S. interlocutors noted in the course of research for this project, the United States does not do a good job of predicting where future conflicts will arise requiring U.S. ground forces. The point here is that a future conflict in Korea is the most likely scenario in which the U.S. Army is likely to become engaged in major combat operations on the ground in Asia.

${ }^{160}$ See, for example, and transcripts, CNA Army Workshop report, Wuthnow et al., U.S. Army in Asia: Opportunities and Challenges: Report of Workshop of Experts. 
- Second, weapons of mass destruction might be in play. It is unclear what circumstances might cause North Korea to use nuclear and/or chemical weapons, or what might happen to these weapons in the event of a regime collapse.

- Third, any conflict on the Korean Peninsula has the potential to involve third parties such as China, Japan, and Russia. There is considerable uncertainty as to how these countries would react in the event of a conflict, and there would be a considerable chance of a major miscalculation by any of the actors.

- Fourth, any conflict would significantly impact the Chinese, Japanese, and South Korean economies (which are, respectively, the 2nd, 3rd, and 14th largest GDPs in the world), and would potentially have a significant impact on the United States as well. ${ }^{161}$

- Fifth, however much South Korean military capabilities may improve in the coming years, demographic changes and a shrinking pool of future conscripts mean that the South Korean Army will be smaller and Seoul will likely continue to look to the United States for assistance in a future conflict. ${ }^{162}$ This will especially be the case if large-scale stability operations are necessary in the wake of a catastrophic collapse of the Pyongyang regime. One think tank study suggests that in such an event, between 8 and 20 U.S. brigades would be needed to assist South Korean forces. ${ }^{163}$

The need to deter a potential conflict in Korea and, if necessary, to be able to fight and win represents one of the principal demands on the U.S. Army's role in Asia. ${ }^{164}$ On the Korean Peninsula, the U.S. Army has both specified and implied requirements. These include but are not necessarily limited to:

- Deterring potential aggression from North Korea. ${ }^{165}$

\footnotetext{
${ }^{161}$ World Bank, official website, http://databank.worldbank.org/data/download/GDP.pdf, last accessed October 15, 2013.

${ }^{162}$ Interviews with U.S. subject matter experts, 2013.

${ }^{163}$ See Bruce W. Bennett, Preparing for the Possibility of a North Korean Collapse Scenario, RAND Corporation, 2013, available at http://m.rand.org/pubs/research_ reports/RR331.html.

${ }^{164}$ Statement made by then deputy secretary of defense Ashton B. Carter, "Defense Priorities in an Era of Constrained Budgets"; interviews with USPACOM officials, 2012 and 2013; interviews with U.S. Army officials, 2013.

165 "Eighth Army Mission" statement, official website of the Eighth Army, http://Eightharmy.korea.army.mil/mission.asp, last accessed October 2, 2013.
} 
- Reassuring South Korea and Japan through permanent presence, rotational presence, combined exercises, staff coordination, and interoperability. ${ }^{166}$

- Conducting combined operations with South Korean forces in response to a North Korean attack. ${ }^{167}$

- Providing humanitarian assistance for civilians. ${ }^{168}$ A North Korean collapse could lead to a widespread humanitarian crisis that would likely require the U.S. Army to give support both in South Korea and in the North. ${ }^{169}$

- Assisting South Korean forces in establishing order and stability in North Korea, including continuing combat operations against North Korean security forces. ${ }^{170}$

- Securing nuclear, chemical, and biological weapons in North Korea. ${ }^{171}$

- Providing air and missile defense for U.S. forces as well as South Korea and Japan. ${ }^{172}$

- Interacting with Chinese forces if, as some observers expect, they enter North Korea in response to a refugee crisis or other reason in order to secure Chinese interests. ${ }^{173}$

- Planning for, and carrying out, a noncombatant evacuation operation (NEO) for U.S. citizens from South Korea. ${ }^{174}$

\footnotetext{
${ }^{166}$ Interviews with U.S. Army officials, 2012 and 2013; interviews with USPACOM, USFK, and U.S. Marine officials, 2013.

${ }^{167}$ Interviews with USPACOM officials, 2013; and interviews with Korean government think tank analysts, 2013.

${ }^{168}$ Interviews with USFK and U.S. Army officials, 2013.

${ }^{169}$ TRADOC, The U.S. Army Capstone Concept, PAM 525-3-0, 19 December 2013, p. 7.

170 Interviews with U.S. subject matter experts, 2013. These interviewees suggested that stabilizing the North in the wake of a conflict and or a regime collapse would be a task largely left to the South Koreans.

${ }^{171}$ Interviews with USFK and U.S. Army officials, 2013; and TRADOC, The U.S. Army Capstone Concept, TRADOC PAM 525-3-0, 19 December 2013, p. 7.

172 Interviews with U.S. non-government subject matter experts, U.S. Army and USPACOM officials, 2013.

${ }^{173}$ Interviews with US subject matter experts, 2013.

${ }^{174}$ The U.S. Eighth Army would have the lead in a NEO in South Korea. See the Eighth Army's mission statement, http://Eightharmy.korea.army.mil/mission.asp. Such an operation would likely be contemporaneous with evacuations of Japanese and Chinese civilians-there are more
} 
In sum, preparing for a Korean conflict remains the largest operational challenge for the United States in the Asia-Pacific region. The U.S. Army has played a vital role in maintaining the peace on the Peninsula for 60 years, and will likely be needed for the foreseeable future. It is critical that the Army continue to deter a conflict through its presence, engagement activities, and demonstrated ability to fight if necessary. The Army's regular revisiting of the requirements needed for the Korean Peninsula will be key to readiness and reassuring allies. As assessed requirements and available resources change, it is important to continue to be sensitive to how those changes affect the way that both Koreas perceive the strength of U.S. commitments on the Peninsula.

\section{Potential contingency in an A2/AD environment}

The U.S. Army also needs to consider the possibility of a contingency that takes place in an environment with an adversary that has A2/AD capabilities. ${ }^{175}$ Countering these capabilities and ensuring U.S. access is a primary mission for the joint force in supporting national security objectives. ${ }^{176}$ The Army has an important role as part of the joint force in countering $\mathrm{A} 2 / \mathrm{AD}$ capabilities-especially in air and missile defense, command and control, communications, and sustainment. ${ }^{177}$

Within the Asia-Pacific region, subject matter experts' concerns over operating in an $\mathrm{A} 2 / \mathrm{AD}$ environment primarily center on China, which is developing an extensive range of capabilities ${ }^{178}$ that could be used to deny the United States access to parts of the Western Pacific in the event of a conflict. ${ }^{179}$ As A2/AD capabilities become more widely available, another possibility raised by some analysts and government documents is that other Asian states, or possibly non-state actors, may also develop

Chinese than American citizens in South Korea. This might require the Army to liaise with both Japanese and Chinese militaries and their interagencies in order to coordinate evacuation efforts.

${ }^{175}$ In such a conflict, the opposing force, either a hostile state or a non-state actor-such as a terrorist group-is in possession of weapons which have the capability to either prevent access by ships and planes to a specific area or deny the ability to operate within that area.

${ }^{176} 2012$ Defense Strategic Guidance; and Department of Defense, Capstone Concept for Joint Operations: Joint Force 2020, 10 September, 2012, p. 1, available at http://www.dtic.mil/ futurejointwarfare/concepts/ccjo_2012.pdf.

177 See Department of Defense, Joint Operational Access Concept, January 2012, especially section 9; and TRADOC, The U.S. Army Capstone Concept, pp. 12, 17, 24, 30, and 33.

178 See Office of the Secretary of Defense, Annual Report to Congress: Military and Security Developments Involving the People's Republic of China, 2011, 2012, and 2013.

${ }^{179}$ Department of Defense, 2006 Quadrennial Defense Review, pp. 29-30; and Department of Defense, Annual Report to Congress on Chinese Military Power 2013, pp. 32-33. 
these capabilities for possible use against the United States and its partners. ${ }^{180}$ Based on U.S. government documents and various U.S. think-tank studies, potential scenarios include but are not limited to:

- A contingency involving possible actions by a state or non-state actor that threaten freedom of navigation through vital shipping lanes such as those in the South China Sea or vital chokepoints such as the Strait of Malacca. ${ }^{181}$

- A contingency in which China may use its A2/AD capabilities in a conflict with Japan over the Senkaku/Diaoyu Islands either to deter or to prevent U.S. intervention in defense of Japan. ${ }^{182}$

- A Taiwan Strait contingency in which China might use A2/AD capabilities in order to deter or prevent outside intervention. ${ }^{183}$

- A contingency in the South China Sea involving a potential conflict over disputed territories in which one or more claimants use A2/AD weapons to close disputed areas to opponents as well as outside powers. ${ }^{184}$

The U.S. Army has the potential to complement the joint force, and partner countries, in responding to $\mathrm{A} 2 / \mathrm{AD}$ threats in several ways:

180 Several Asian military officials and subject matter experts interviewed for this study discussed the possibility of developing anti-access/area denial capabilities to counter China. On non-state actors using land-based anti-ship missiles and other A2/AD technologies, see Frank Hoffman, Conflict in the 21st Century: The Rise of Hybrid Wars (Arlington, VA: Potomac Institute for Policy Studies, 2007).

${ }^{181}$ General Norton A. Schwartz, USAF, and Admiral Jonathan W. Greenert, USN, "Air-Sea BattlePromoting Stability in an Era of Uncertainty," The American Interest, February 20, 2012, available from www.the-american-interest.com/article.cfm?piece=1212.

${ }^{182}$ Interviews with Japanese defense officials, 2013. For a comprehensive study of a possible future conflict between China and Japan and how China might use its A2/AD capabilities, see Michael D. Swaine, Mike M. Mochizuki, Michael L. Brown, Paul S. Giarra, Douglas H. Paal, Rachel Esplin Odell, Raymond Lu, Oliver Palmer, Xu Ren, China's Military and the U.S.-Japan Alliance in 2030: A Strategic Net Assessment, Carnegie Endowment for Peace, May 2013, available at http://carnegieendowment.org/2013/05/03/china-s-military-and-u.s.-japan-alliance-in-2030strategic-net-assessment/g1wh.

${ }^{183}$ Department of Defense, Annual Report to Congress on Chinese Military Power 2013, pp. 32 33.

${ }^{184}$ As of 2013, China was the only country in the region that would have such capabilities. Interviews by CNA analysts in 2011 suggested that at least some Vietnamese military officials are thinking about acquiring such capabilities. Some Japanese interviewees also argued that Japan should acquire its own A2/AD capabilities. One U.S. subject matter expert has pointed out to the authors that shore-based anti-ship missiles are an easy way for smaller countries to counter China's growing capabilities in the South China Sea. Interviews with Vietnamese military officials, 2011; interviews with Japanese Defense Ministry officials, 2013; interview with U.S. subject matter expert, 2013. 
- The U.S. Army provides missile and air defense for U.S. and allied assets stationed in the region. This includes defense of U.S. and allied airbases that might be threatened by enemy missiles as well as protecting ships in port. While the U.S. Navy also has assets such as the Aegis, which can provide defense of ports and airfields, the use of land-based Army anti-missile forces can free up naval assets that might be required elsewhere. ${ }^{185}$

- Some observers see the U.S. Army as also potentially playing a forced-entry role to deny non-state actors the ability to use A2/AD weapons from areas near chokepoints. ${ }^{186}$

- The U.S. Army also provides key command and control and satellite communication capabilities, which are critical in coordinating combined and joint forces.

- Indirectly, U.S. Army engagement with countries in the region can increase the likelihood that the U.S. military will be able to access key ports and other facilities during any response to a crisis in the region involving A2/AD capabilities. U.S. air and naval assets that are needed to defeat an opponent will likely require permission to use facilities in partner and allied countries, and the Army can play an important role in facilitating access agreements, particularly in countries with army-dominated militaries.

\section{Internal instability}

Internal instability remains an ongoing security concern in many parts of the region, especially South and Southeast Asia. Insurgent groups are active in India, Burma, Thailand, Indonesia, and the Philippines. Furthermore, the U.S. intelligence community publically assesses that factors such as demographic change, incomplete or failed transitions to democracy, and food and water shortages are likely to continue to fuel instability in South and Southeast Asia (and other parts of the world) for the next 15-20 years. ${ }^{187}$ Political instability, religious and ethnic tensions, threats

\footnotetext{
${ }^{185}$ Interview with US military officials, 2013; see also John Gordon IV and John Matsumura, The Army's Role in Overcoming Anti-Access and Area Denial Challenges, RAND Corporation, 2013.

${ }^{186}$ Interview with U.S. military official, 2013. See also Nathan Freier, "The Emerging Anti-Access, Area Denial Challenge."

187 Office of the Director of National Intelligence, Remarks as delivered by James R. Clapper, Director of National Intelligence, "Worldwide Threat Assessment," delivered to the House Permanent Select Committee on Intelligence, April 11, 2013; and National Intelligence Council, Global Trends 2030. See also Asian Development Bank, Asian Water Development Outlook 2013, Manila, Philippines, 2013.
} 
to public order, and insurgencies are therefore likely to continue to be security problems for countries of interest in Asia. ${ }^{188}$

While the U.S. Army has been involved in a number of counterinsurgency and stability operations in the region since $1898,{ }^{189}$ analysis of the data available for this study suggests that there is little appetite for the Army to be involved in fighting a counterinsurgency in Asia in the near term. In part, this reflects the fact that current internal stability problems are not a direct threat to U.S. objectives, discussed in the previous chapter. It also reflects the fact that countries such as India and Burma do not want U.S. direct involvement in dealing with their insurgency threats, ${ }^{190}$ and that most of the Asian countries that are of major importance to American national interests have the capacity to manage internal threats mostly on their own. This stands in marked contrast to some assessments of the Middle East, which see a very different landscape. ${ }^{191}$

However, there does appear to be considerable regional interest in U.S. military personnel helping develop local capacity to respond to internal threats, which may generate a demand for help through the foreign internal defense (FID) program. U.S. Army general purpose and special forces will likely be asked to assist a country's forces in training, planning, and other activities that help build the capacity of that country to respond to internal threats. A good example is Operation Enduring Freedom-Philippines, which began in 2001. Army units have been rotating through the Philippines and assisting Philippine security forces in countering extremist groups in the south of the country. ${ }^{192}$ Another good example is TRADOC's Asymmetric Warfare Group, which supports U.S. efforts to assist partner countries in developing capabilities and training programs to counter asymmetric threats. ${ }^{193}$

\footnotetext{
${ }^{188}$ Interviews with senior Philippine officials, 2013.

${ }^{189}$ For a concise history of the campaigns of the U.S. Army in the Pacific, see Naughton, The U.S. Army in the Pacific. On counterinsurgency in the Philippines before World War II, see also Brian McAllister Linn, Guardians of Empire: The U.S. Army in the Pacific, 1902-1940, (Chapel Hill, North Carolina: University of North Carolina Press, 1999).

${ }^{190}$ Interviews with Indian military officials and think tank analysts, 2013.

${ }^{191}$ See, for example, Nathan Freier et al., Beyond the Last War: Balancing Ground Forces and Future Challenges Risk in USCENTCOM and USPACOM; and Colonel Michael R. Eastman, "American Land Power and the Middle East of 2030," Parameters, Autumn 2012, last accessed February 10, 2013, http://strategicstudiesinstitute.army.mil/pubs/parameters/Articles/2012autumn/Eastman.pdf.

${ }^{192}$ For background information on U.S. military assistance to the Philippines in its efforts to defeat VEOs in the southern Philippines, see Thomas Lum, The Republic of the Philippines and U.S. Interests, Congressional Research Service, April 5, 2012.

${ }^{193}$ Interviews with U.S. Army officials, 2013.
} 
The U.S. Army's counterinsurgency and other related skills will likely be needed in order to assist regional armed forces through training, planning, financial assistance, and other forms of assistance. ${ }^{194}$ In particular, U.S. expertise developed over the past 12 years in Iraq and Afghanistan makes the U.S. Army and U.S. Marines valuable partners for countries looking to learn from their experience. ${ }^{195}$

\section{Terrorism}

While most countries in the region are concerned with the threat of terrorism, ${ }^{196}$ select South and Southeast Asian countries are currently the most vulnerable. ${ }^{197}$ Countries that have had significant terrorist attacks since 2000 include India, Pakistan, the Philippines, Nepal, Indonesia, Thailand, Bangladesh, Maldives, and Sri Lanka. Terrorist activities are a major concern for U.S. security interests, as they pose a threat to allies and key partners and may pose a threat to the U.S. homeland as well. ${ }^{198}$

While much of the U.S. Army's current counterterrorism activities in the region are focused on the Philippines, ${ }^{199}$ there is widespread regional interest in exchanges with the U.S. military on counterterrorism. ${ }^{200}$ There will be multiple opportunities for the

\footnotetext{
${ }^{194}$ Wuthnow et al., U.S. Army in Asia: Opportunities and Challenges: Report of Workshop of Experts; interviews with U.S. Army officials, 2013.

${ }^{195}$ Interviews with U.S. Army and U.S. Marine Corps officials, 2013.

196 See, for example, Country Reports on Terrorism 2011, Department of State, Bureau of Counterterrorism, July 2012, last accessed Dec. 31, 2012, at http://www.state.gov/ documents/organization/195768.pdf; Foreign Terrorist Organizations, Department of State, Bureau of Counterterrorism, Sep. 28, 2012, last accessed Jan. 3, 2013, at http://www.state.gov/j/ct/rls/other/des/123085.htm; Peter Chalk et al., The Evolving Terrorist Threat to Southeast Asia, RAND Monograph MG-846. 2009, last accessed Jan. 2, 2013, at http://www.rand.org/content/dam/rand/pubs/monographs/2009/RAND_MG846.pdf; and Bruce Vaughn et al., Terrorism in Southeast Asia, Congressional Research Service, Oct. 16, 2009, last accessed Jan. 2, 2012, at http://www.fas.org/sgp/crs/terror/RL34194.pdf.

${ }^{197}$ Office of the Director of National Intelligence, Remarks as delivered by James R. Clapper, Director of National Intelligence, "Worldwide Threat Assessment," delivered to the House Permanent Select Committee on Intelligence, April 11, 2013; and Country Reports on Terrorism 2011, Department of State, Bureau of Counterterrorism, July 2012, last accessed Dec. 31, 2012, at http://www.state.gov/documents/organization/195768.pdf.

${ }^{198}$ Foreign Terrorist Organizations. Department of State, Bureau of Counterterrorism, Sep. 28, 2012, last accessed Jan. 3, 2013, at http://www.state.gov/j/ct/rls/other/des/123085.htm; and Bruce Vaughn et al., Terrorism in Southeast Asia. Congressional Research Service, Oct. 16, 2009, last accessed Jan. 2, 2012, at http://www.fas.org/sgp/crs/terror/RL34194.pdf.

${ }^{199}$ See Lum, The Republic of the Philippines and U.S. Interests (2012).

${ }^{200}$ Indian interlocutors, for example, were quite clear that while they saw benefits from engaging with the United States on terrorism and trans-national threats; there was no interest
} 
Army to engage with countries in terms of doctrinal development and training aimed at developing counterterrorism capabilities including enhancing the ability of special operations and general purpose forces to operate together. ${ }^{201}$ In addition, this is an area of potential cooperation that extends to almost every country in the region, including China. Counterterrorism may be a good means of developing military-to military relationships when other types of military cooperation are not feasible.

\section{Transnational security threats}

Transnational criminal activities-such as weapons and drug smuggling, piracy, illegal migration, illicit trade in timber and other natural resources, and human trafficking-are widespread in many parts of the region and have been identified by several Asian official white papers and subject matter experts as a major security concern. ${ }^{202}$ Such activities can threaten the integrity of national borders, spread corruption and undermine the authority of governments, and harm economic prosperity. ${ }^{203}$

While countering these types of threats is not often viewed as a major mission for the U.S. Army, it may play a role in complementing the U.S. interagency in countering transnational crime in the region. The Army contributes to Joint Interagency Task Force West (JIATF-West), which is the executive agent for DoD support to law enforcement in counterdrug operations in the USPACOM area of responsibility, and there is at least some interest in developing similar capabilities in the Philippine army. ${ }^{204}$ U.S. Army personnel can also help with providing local security forces with

in a U.S. role on Indian soil. Interviews with Indian civilian officials, 2013. Similar views were expressed in interviews with Philippine and Vietnamese military and civilian officials.

${ }^{201}$ Interviews with U.S. Army officials, 2013.

202 See, for example, Vietnam: National Defence, Ministry of National Defence, Vietnam, December 2009, pp. 18, 26, available at http://merln.ndu.edu/whitepapers/Vietnam2009.pdf; Strong and Secure: A Strategy for Australia's National Security, Department of the Prime Minister and Cabinet, Australia, January 2013, p. 11, available at http://www.dpmc.gov.au/national_security/docs/national_security_strategy.pdf; and Rizal Sukma, "Indonesia's Security Outlook and Defence Policy 2012," in Security Outlook of the Asia Pacific Countries and Its Implications for the Defense Sector (Tokyo: National Institute for Defense Studies, Japan, 2012), p. 7.

${ }^{203}$ See, for example, Strong and Secure: A Strategy for Australia's National Security, Department of the Prime Minister and Cabinet, Australia, January 2013, p. 11, available at: http://www.dpmc.gov.au/national_security/docs/national_security_strategy.pdf; and Office of the Director of National Intelligence, Remarks as delivered by James R. Clapper, April 11, 2013, pp. 5-6.

${ }^{204}$ Interviews with senior Philippine military officials, 2013. For more on JIATF-West, see the JIATF West home page, http://www.pacom.mil/organization/staff-directorates/jiatfwest/ index.shtml. 
training and planning skills, as well as assisting in the development of their information, surveillance, and reconnaissance capabilities. ${ }^{205}$

\section{Natural disasters}

As Typhoon Haiyan amply demonstrated when it hit the Philippines in November 2013, natural disasters can represent a significant threat to human security. In 2012, the Asia-Pacific region experienced 93 natural disasters, which affected some 75 million people. ${ }^{206}$ It is one of the most disaster-prone regions in the world: ${ }^{207}$ it is prone to typhoons and cyclones; it contains some of the world's most active faults and volcanos; and many areas experience massive flooding. As former USARPAC commander Lieutenant General Wiercinski has noted, the only questions are when and where the next big disaster will occur. ${ }^{208}$

Admiral Locklear, Commander, USPACOM has noted that climate change is one of the region's most pressing security challenges. ${ }^{209}$ While the ability to respond to natural disasters varies widely among countries in the region, even advanced countries can require international assistance, as Japan did after the March 2011 earthquake and tsunami.

While the United States will not be asked to respond to every disaster, being able to support regional partners faced with major humanitarian crises can contribute to the long-term stability of the region and build goodwill. U.S. military forces, including the U.S. Army, can bring key enabling capabilities to any interagency response. For example, the Army can provide command-and-control elements to coordinate relief efforts, engineers and other specialized units to restore infrastructure, and logistics and sustainment capabilities to move needed supplies.

\footnotetext{
${ }^{205}$ Legal and security issues related to transnational migration issues and the possibility of U.S. Army assistance in training were specifically raised to the authors by a Burmese government representative. Interview with Burmese government official, 2013.

206 United Nations, Office for the Coordination of Humanitarian Affairs, "Humanitarian Snapshot: Natural Disasters in Asia-Pacific-2012," last accessed September 4, 2013, at http://reliefweb.int/ sites/reliefweb.int/files/resources/ROAP_Snapshot_disasters_2012.pdf.

${ }^{207}$ Interviews with USPACOM officials, 2012 and 2013.

${ }^{208}$ Comments made at the Association of the United States Army LANPAC Symposium and Exhibition, Honolulu, Hawaii, April 9-11, 2013.

${ }^{209}$ See "The Posture of the U.S. Pacific Command and U.S. Strategic Command," transcript from the House Armed Services Committee," March 5, 2013, par. 54, http://www.pacom.mil/ commander/statementstestimony/20130305-hasc-uspacom-posture-transcript.shtml.
} 


\section{Concluding thoughts}

Based on the above review of the national security objectives and survey of the security landscape, there is a range of issues that the U.S. Army should consider in thinking about how it can best support U.S. objectives and what it will need to be able to do in the Asia-Pacific region:

- Deterrence remains a critical task for the U.S. military in the region. An important U.S. national objective is the maintenance of economic prosperity, and that relies on deterrence and the U.S. military's ability to engage and shape the region.

- There is a strong demand by those in the region for the U.S. Army to continue engaging at multiple levels, reinforcing existing efforts but also finding new ways to work together to respond to the changing strategic environment.

- Operations, actions, and activities will need to be adjusted in a region that is rapidly evolving. The rises of China and others are changing the strategic landscape-creating new opportunities and concerns which will require adjustments and reprioritization.

- Attitudes toward the United States are changing in ways that are both positive and potentially negative. U.S. Army operations, actions, and activities, as well as the perceptions they create, will need to be carefully managed and communicated. The Army should consider how it can reinforce positive attitudes toward the United States while mitigating concerns over whether the U.S. can continue upholding its commitment.

- Distance will always be a challenge for flowing forces into and across the region and for maintaining a credible presence. The U.S. Army should rethink ways it can maintain needed presence through rotations, exchanges, and staff visits, especially in a challenging fiscal environment. Well-timed exchanges and official visits can be an effective means of communicating Army and U.S. presence and commitment.

- Regional and country expertise is needed to inform planners on domestic political issues, cultural concerns, and historical legacies that might impact operations and activities or impose challenges for trilateral and multilateral activities.

- The most likely potential fights that the U.S. Army will need to prepare for in the region are: (1) a conflict on the Korean Peninsula, (2) a conflict in an A2/AD environment, and (3) counterterrorism. Therefore, the Army will need to continue to maintain a varied set of capabilities appropriate to each and the 
ability to surge those capabilities into and across the region in the event of a crisis. As always, finding the right balance of capabilities to be ready will be a challenge.

- The U.S. Army also needs to be prepared to provide foreign internal defense, transnational crime, natural disasters, and other non-traditional threat assistance.

- The U.S. Army's capability to plan, its capacity to engage, and its ability to resource responses to these varied requirements will significantly tax the Army in theater. The Army will need to revisit all three to ensure that it is ready to meet emerging challenges.

In sum, we assess that, based on national security objectives and the security landscape, and in order to meet the national command authority and COCOM guidance, the U.S. Army has a critical and varied role in the Asia-Pacific region that will require it to draw on a wide range of abilities. The next chapter will discuss those capabilities and key considerations for the Army. 


\section{Chapter 4: Key Considerations for the U.S. Army}

As the preceding analysis of U.S. national security objectives and evolving strategic landscape indicates, the U.S. Army has a critical and varied role in the Asia-Pacific region that will require it to draw on a wide range of capabilities. Much as it does in other parts of the world, the Army needs to be able to

- deter adversaries;

- respond to a wide range of traditional and non-traditional contingencies;

- build partner capacity;

- strengthen relationships;

- shape the security environment;

- enable the joint force and interagency to meet national objectives and support them in doing so; and

- conduct operations, actions, and activities in a diverse and changing region.

In this chapter, we discuss and analyze the key issues that the U.S. Army should consider in terms of supporting U.S. objectives in the Asia-Pacific region. Specifically, we discuss: (1) what the Army will likely need to be able to do, given national objectives and key features of the strategic landscape; (2) what key capabilities the Army will need in order to provide that support; and (3) what the Army should consider as a service, as part of the joint force, and to complement the interagency.

For the purposes of this study, we have organized the discussion of what the U.S. Army needs to do into three categories: fight, enable, and shape. Each category supports U.S. national security objectives in a different way, and each requires distinct capabilities (although there is some overlap).

- Fight. First and foremost, the U.S. Army needs to have credible land power force in order to meet potential conflicts that the United States may face in the region. This includes the abilities to fight in a major conflict on the Korean Peninsula, to contribute to the fight in an A2/AD environment, and to fight 
terrorism. The Army has unique contributions to make in each of these potential fights. Furthermore, the Army's recognized land combat capabilities contribute to maintaining credible deterrence, which helps maintain the stability and economic prosperity in the region.

- Enable. The U.S. Army has a key role to play in enabling the many types of joint, interagency, combined, and multinational efforts that the United States may want to carry out in Asia. The Army brings critical capabilities - such as engineers, missile defense, military police, communications, and logisticswhich are needed to support and enable theater-level operations and contingency responses by the joint force U.S. civilian agencies, and allies and partners.

- Shape. The U.S. Army needs to be able to shape the regional environment in order to influence both partners and potential adversaries through engagement and deterrence. This is a critical task that serves to support U.S. objectives in the region and sets the theater for future operations. As noted in the previous chapter, many of the stated U.S. national security goals rest on the ability to build and enhance relationships with allies, partners, and rising powers such as China and India. Furthermore, U.S. national security interests are best served by a region that is peaceful, that is stable, and that is one in which countries respect international rules and norms.

This chapter explores each of these in turn and offers some final thoughts and recommendations.

\section{Fight}

Should deterrence fail, the U.S. Army might be called upon to undertake certain conventional, asymmetric, and unconventional fights in the Asia-Pacific region: a contingency on the Korean Peninsula, a contingency in an A2/AD environment, and counterterrorism.

\section{A contingency on the Korean Peninsula}

As noted in the previous chapter, a conventional contingency on the Korean Peninsula is one of the worst-case scenarios facing U.S. interests in the region. Key 
capabilities that the U.S. Army will need in order to deter-and if necessary, fightinclude those discussed below. ${ }^{210}$

- The U.S. Army must be able to provide ground forces in order to conduct combat operations as part of United States Forces Korea/Combined Forces Command/United Nations Command. Eighth Army would serve as a combined joint task force (CJTF) that would contribute to decisive operations in the Korean theater of war to defeat North Korean forces. Beyond combat, combat support, and combat service support forces, the U.S. Army brings to the Korean Peninsula great experience in integrating the operations of the forces of numerous different countries, always a daunting task.

- The U.S. Army must be able to provide command-and-control capabilities needed to conduct joint and combined operations. The Army provides critical command and control capabilities that the joint force will need in order to conduct operations in a Korean contingency (or other contingencies in the region, for that matter).

- The U.S. Army will need to provide air and missile defense to counter North Korean threats to U.S. and allied assets in South Korea, Japan, and Guam. North Korea has growing missile capabilities and can now threaten targets in Japan and Guam as well as South Korea. The Army's missile defense capabilities will be needed to protect U.S. and allied assets in South Korea and Japan as well as to protect Guam.

- The U.S. Army must be able to provide theater-level logistics support to the joint force without which that force cannot effectively fight. The Army's sustainment capabilities are critical for enabling the joint force in this and other theater-level contingencies.

- The U.S. Army would be a major player in evacuating U.S. citizens in South Korea should a crisis occur. Eighth Army would help organize a NEO and would work with the other services to ensure the safe evacuation of U.S. citizens and others. The Army and other services also might have to coordinate with other countries, which would likely be conducting NEOs of their own.

- The U.S. Army might need to provide forces and specialized units to secure North Korea's WMD in the event of a collapse. North Korea has nuclear,

${ }^{210}$ TRADOC Army Operating Concept 2016-2028, pp. 30-34; TRADOC, The U.S. Army Capstone Concept; DoD, The Joint Operational Access Concept; The Joint Capstone Concept; 2012 Army Strategic Planning Guidance; and interviews with senior U.S. military and civilian officials, 2013. See also Bruce Bennett, Preparing for the Possibility of a North Korean Collapse, RAND Corporation, 2013, available at http://m.rand.org/pubs/research_reports/RR331.html. 
chemical, and biological weapons. Securing these weapons following a collapse of the Pyongyang regime would clearly be a high priority for the United States. Retaining the capability to provide such forces on the Korean Peninsula will be important both for deterrence and for rapid response.

- The U.S. Army must be able to provide chemical warfare and other specialists to conduct consequence management should WMD be used. In a crisis, some of the North's nuclear, chemical, and biological weapons might be used either against South Korea or in North Korea. ${ }^{211}$ In such an event, the Army would likely be needed to help provide containment, emergency relief, and decontamination capabilities.

- The U.S. Army must be able to provide humanitarian assistance, civil affairs units, military police, and other forces to assist South Korean forces in restoring order in a post-collapse North Korea. A North Korean collapse would likely be followed by a large-scale humanitarian crisis that would need to be addressed. ${ }^{212}$ In addition, it might take considerable time to restore order in the North, especially if elements of the former regime resist South Korean forces. It is unclear whether South Korea would have sufficient means to conduct stability operations on its own, and U.S. assistance might be needed.

- The U.S. Army might need to assist with a refugee crisis. If so, it would need to provide military police and other units to assist the South Korean government. Even if South Korean forces did not move north of the demilitarized zone, a crisis in North Korea could generate significant refugee flows into South Korea, and the Army might be called upon to assist.

\section{Key considerations}

Deterring war on the Korean Peninsula remains of critical importance, especially in an era of constrained resources. Current plans for rotations of forces into Northeast Asia can be leveraged as an additional means of signaling North Korea as well as helping U.S. Army personnel become more familiar with the theater of operations. ${ }^{213}$ The Army should also continue to develop ways to further coordinate between institutional and operational commands in planning visits by senior Army leaders and sending strategic messages aimed at Pyongyang in order to further enhance deterrence.

\footnotetext{
${ }^{211}$ Interviews with U.S. Korea subject matter experts, 2013.

${ }^{212}$ Bennett, Preparing for the Possibility of a North Korean Collapse; interviews with U.S. nongovernment subject matter experts, 2013; and transcripts, CNA Army Workshop report, Wuthnow et al., U.S. Army in Asia: Opportunities and Challenges: Report of Workshop of Experts.

${ }^{213}$ Interviews with USFK officials, 2013; interviews with U.S. Army officials, 2013.
} 
Reassuring South Korea and Japan, especially in the evolving security environment, is critical. U.S., Japanese, and Korean interlocutors all underscored concerns with regard to signaling continued commitment to Japan and South Korea. ${ }^{214}$ The U.S. Army should periodically revisit how it is engaging with these two allies, to ensure that engagement activities address evolving allied concerns and reflect the changing security environment in Northeast Asia. Capturing lessons learned from past engagements should also be stressed in order to further fine tune messaging aimed at allies (and others). It is important to emphasize that any further reductions in force that may impact existing forces on the Peninsula will have to be managed carefully in order to avoid creating doubts among allies and potential adversaries.

Engagement activities with the Chinese military may provide an important means of reinforcing U.S. national security objectives tied to the Korean Peninsula. As noted in the previous chapter, a Korean contingency has the potential to impact China and it is unclear how Beijing might react. Engagement might help the Army (and other U.S. military planners) better understand how China might respond to a crisis and might provide groundwork for commanders to work with Chinese forces should they become involved.

A North Korean collapse could come quickly. In order to strengthen credibility and the ability to reassure Seoul as North Korean and South Korean capabilities evolve, it will be important to ensure that the U.S. Army has the appropriate mix of initial and follow-on assets readily available in an emergency.

\section{A contingency in an A2/AD environment}

The U.S. Army must also be prepared to take part in a conflict in which an adversary has asymmetric A2/AD capabilities. Countering these capabilities and ensuring U.S. access is a primary mission for the joint force in support of national security objectives. The Army has an important enabling role in such a contingency-and with the spread of $\mathrm{A} 2 / \mathrm{AD}$ technologies, the demand for Army capabilities that can help counter such technologies is likely to increase.

The U.S. Army needs to retain abilities that contribute to the joint force's capacity to operate in an A2/AD environment. These include but are not necessarily limited to the ones described below:

${ }^{214}$ Interviews with U.S. State Department, USFK, and U.S. Army officials, 2013; interviews with South Korean government think tank analysts, 2013; and interviews with Japanese defense officials, 2013. 
- The U.S. Army needs to retain its ability to provide air and missile defense for U.S. and allied assets at ports and on land. Given the range of existing A2/AD capabilities, U.S. and allied ships and planes in regional ports and airfields will potentially be at risk from missile and air strikes in a crisis. ${ }^{215}$ Army capabilities will likely be needed to protect regional transportation hubs and U.S. and allied bases.

- As it would in a Korean contingency, the U.S. Army will need to provide command-and-control capabilities to the joint force. ${ }^{216}$ The Army provides a significant portion of the communications capability that would be needed in a major air-sea campaign to counter an adversary with A2/AD capabilities, both for the joint force and in integrating any allied forces that might be participating. ${ }^{217}$

- As in Korea, the U.S. Army will need to provide theater sustainment for the joint force in an air-sea campaign. ${ }^{218}$

Against a non-state actor with anti-access/area-denial capabilities, the U.S. Army may be called upon to carry out forced entry or assaults along the littoral in order to deny ground space to an opponent. This may involve general purpose and/or special forces as well as Marine capabilities. Long-term presence may be required until a crisis is resolved.

\section{Key considerations}

Given the widely held belief that China will continue to develop capabilities that could be used for $\mathrm{A} 2 / \mathrm{AD}$, and that other countries - possibly even non-state actorswill likely be able to develop or acquire A2/AD technology, the U.S. Army will probably see a greater demand for its anti-missile and other relevant capabilities.

It is critical to have the right mix of capabilities available to the region to support the A2/AD fight. While there is some overlap with capabilities needed in a Korean scenario-for example, command and communications and logistics capabilities - the

215 Department of the Army, 2013 Army Posture Statement, p. 4, available at http://usarmy.vo.llnwd.net/e2/c/downloads/302970.pdf; interviews with U.S. Army officials, 2013; and Gordon and Matsumura, The Army's Role in Overcoming Anti-Access and Area Denial.

${ }^{216} 2013$ Army Posture Statement, p. 4; The U.S. Army Capstone Concept, p. 14; and interviews with USPACOM officials, 2013.

${ }^{217}$ Interview with U.S. Army officials, 2013.

${ }^{218} 2013$ Army Posture Statement, p. 4; The U.S. Army Capstone Concept, p. 14; and interviews with USPACOM officials, 2013. 
mix of capabilities is not identical. In order to ensure that the needed levels of capabilities for both types of contingency are available in a resource-constrained environment, the U.S. Army should revisit how it prioritizes capabilities as the security environment changes. This is especially the case for air and missile defense, as there is likely to be greater demand for such capabilities throughout the theater. ${ }^{219}$

Any operation against an adversary with A2/AD capabilities will likely be primarily maritime and air in nature and will require access to ports and air fields in allied and partner countries. The U.S. Army needs to revisit its engagement activities to ensure that it is helping lay the groundwork for future access in a time of crisis. As most militaries in the region are dominated by land forces, the Army is in a good position to leverage its relationships with regional armies to promote that access.

\section{Counterterrorism}

Terrorist organizations in the region present a potential threat to the U.S. homeland as well as to key allies and partners. While concern over terrorism is fairly widespread across the Asia-Pacific, terrorist activities have been especially problematic in South and Southeast Asia. The U.S. military will need to maintain its ability to conduct counterterror operations in the region, including its ability to conduct combined operations in conjunction with allies, partners, and others, as well as to help them build partner capacity.

Abilities that the U.S. Army needs to retain include but are not necessarily limited to those described below:

- The U.S. Army will likely need to continue to provide special and general purpose forces that can be used in support of operations and to improve the counterterror capabilities of regional forces. While the other services also contribute to this effort, the Army provides nearly half of all special operations forces. ${ }^{220}$ Over the last 12 years in Iraq and Afghanistan, the Army has gained experience in leading and coordinating special forces and general purpose troops in counterterror and counterinsurgency operations. The specialized skills it has gained will likely be of great interest to countries in the region. ${ }^{221}$

\footnotetext{
${ }^{219}$ Interview with USPACOM officials, 2013.

${ }^{220}$ Interview with U.S. Army officials, 2013.

${ }^{221}$ Ibid.; interviews with USPACOM officials, 2013.
} 
- The institutional U.S. Army will need to continue to support efforts in the region through exchange activities such as the ongoing TRADOC's Asymmetric Warfare Group to build partner capacity throughout the region. This will not only enhance the ability of regional partners to address their own security concerns, it will also help develop partner capacity to operate with U.S. forces and provide the United States with better insights into local threats.

- In order to enhance effectiveness in counterterror operations, the U.S. Army will need to continue to develop personnel who have knowledge of local political and social conditions and can assist in the planning and execution of counterterror operations. Successful operations depend in part on the ability to operate among the civilian population and to cultivate knowledge of local operating conditions.

\section{Key considerations}

The U.S. Army needs to consider ways it can train, retain, promote, and employ personnel with regional expertise. In order to effectively operate in the region and build partner capacity, planners and operators will likely need to draw on knowledge of local conditions in countries as diverse as the Philippines, Bangladesh, and Thailand in thinking about counterterror operations. Interviews with HQDA, TRADOC, and other Army organizations indicated that there are several initiatives to provide greater training and education for officers, NCOs, and civilian personnel in the Army. In addition, personnel need to be tracked and given increased opportunities to serve multiple tours in the region and to be carefully managed for purposes of retention and promotion..$^{22}$

The need to be able to conduct counterterror operations presents a major opportunity for the U.S. Army to further develop and enhance relationships with regional militaries. Concerns over terrorist threats are common across the region, and many militaries are interested in building a greater capacity to respond. The Army therefore has opportunities to build on and expand existing relationships with allies and partners that have terrorism concerns. India, an emerging partner, is also interested in exchanges on counterterrorism. ${ }^{223}$ Counterterrorism may also offer additional opportunities to expand the military-to-military exchanges with China, an important objective for the United States. The Army should think about ways to leverage its experiences in Afghanistan and Iraq so that they will enhance its ability to work with armies in the region.

\footnotetext{
${ }^{222}$ Ibid.

${ }^{223}$ Interviews with Indian think tank analysts, 2013.
} 


\section{Enable}

The U.S. Army also has capabilities with which it can complement the joint force and interagency. Whether responding to natural and man-made disasters, pandemics, and transnational crime or other non-traditional security concerns in the Asia-Pacific region, the Army has unique ground-based capabilities to support contingency operations. These capabilities can "enable" by providing logistics, medical, communications, policing, and many other activities that the Army needs in order to fulfill its missions. While some of these specialized and niche capabilities are also resident in the other services and some civilian agencies, none of them have the range and depth that the Army brings to the table. ${ }^{224}$

Key enabling capabilities that the U.S. Army will likely need in order to complement the joint force and interagency in the Asia-Pacific region include but are not necessarily limited to those described below: ${ }^{225}$

- The U.S. Army provides command-and-control capabilities for joint, interagency, combined, and multinational operations and activities. In addition, the Army has wide experience working with ground forces around the globe and in Asia. That experience can be leveraged by the joint force and interagency in any contingencies which require extensive interaction with local ground forces or senior foreign army leaders.

- The U.S. Army provides logistics and sustainment to support the joint force and interagency in a wide range of non-combat operations. Just as the Army provides support to the theater in a conflict, it provides needed logistics support to the joint force and interagency in non-combat activities such as moving material for USAID and other civilian agencies. ${ }^{226}$

- The U.S. Army can provide a wide range of specialized forces that can help meet the needs of the joint force and interagency. These capabilities, which would otherwise be unavailable or in short supply, include but are not limited to:

\footnotetext{
${ }^{224}$ Interview with U.S. government official, 2013. For example, USAID depends in part on Army logistical support to move vital materials in a crisis response.

${ }^{225}$ TRADOC Army Operating Concept 2016-2028, pp. 30-34; TRADOC, The U.S. Army Capstone Concept; DoD, The Joint Operational Access Concept; The Joint Capstone Concept 2012; Army Strategic Planning Guidance; and interviews with USPACOM officials, 2013.

${ }^{226}$ Interviews with USPACOM officials, 2013; and AUSA, The U.S. Army in the Pacific, pp. 21 and 25.
} 
- Intelligence information on local ground forces, political conditions, and other factors that joint force and interagency may need in planning and executing operations in the region such as activities aimed at transnational criminal activities in the Philippines.

- FAOs and other U.S. Army personnel with FAO-like training who can and do provide area expertise, including valuable regional knowledge, to U.S. military and civilian personnel unfamiliar with Asian political and cultural landscape. ${ }^{227}$ This can be especially valuable in disaster response, foreign internal defense, and civilian evacuations.

- The U.S. Army can deploy its civil-affairs units. The Army provides much of the U.S. military's civil affairs expertise. ${ }^{228}$ This can be a valuable asset in both joint and interagency operations and activities which require liaison with local populations. They also can contribute to U.S. military and civilian agency activities and operations that are aimed at relationship building with key partners in the Pacific.

- The U.S. Army can also provide engineers who have the training equipment that might be needed in responding to man-made and natural disasters. The other services do not have the same capabilities to deploy these types of troops.

- The U.S. Army can also support the interagency by contributing medical expertise in a preventative role or during an epidemic or other crisis. ${ }^{229}$ The Army supplies a significant portion of the medical capability for the joint force in the Asia-Pacific region and would be a key enabler in the event of a pandemic or in responding to a major disaster.

\section{Key considerations}

The data for this study indicate that demand for enabling capabilities in the region is likely to remain high and that a key part of the U.S. Army's role in Asia and the Pacific will be to provide those assets in support of the interagency and joint forces in support of U.S. objectives when needed. The Army, therefore, should consider which of these enabling capabilities are most needed and how to balance the demands for enabling capabilities with the need to be able to fight and shape.

\footnotetext{
${ }^{227}$ Wuthnow et al., U.S. Army in Asia: Opportunities and Challenges: Report of Workshop of Experts.

${ }^{228}$ Interviews with U.S. Army officials, 2013.

${ }^{229}$ Interviews with USPACOM officials, 2012.
} 
The U.S. Army should revisit which capabilities are most in demand and which should have the greatest priority, given U.S. joint force and interagency needs in the Asia-Pacific. As resources become more limited, the Army is likely to have fewer enabling capabilities with which to support the joint force and interagency. Therefore, it should set priorities as to which enabling capabilities are most likely to be needed in the Asia-Pacific region and to be needed by USPACOM and subordinate commands. It should also carefully consider the future balance between specialized functions in the reserve component and those in the active component, as reserve component capabilities cannot always be mobilized in time to respond to emergencies.

In addition, the U.S. Army should revisit its force posture to determine the right mix of enabling capabilities for various contingencies in the Asia-Pacific region. For example, given the likelihood of more frequent weather-related disasters, will more engineers be needed in the region? The Army should also consider tailoring force packages for specific contingencies and needs-e.g., anti-missile forces may be needed more in Northeast Asia, whereas HA/DR-related capabilities may be needed more in Southeast and South Asia.

\section{Shape}

While it is critical that the U.S. Army be able to contribute to the fight if necessary, a key goal is not having to fight. Thus, it is also critical that the Army does its part to help shape the security environment in order to help preserve a peaceful and stable region. The Army does this by contributing to the U.S. military's ability to deter potential aggression in the region, by engaging with allies, partners, and countries of interest such as China, and by sending strategic messages to communicate U.S. commitment and intent.

The U.S. Army brings a wide range of capabilities, programs, institutions, and relationships that facilitate the Army's ability to support U.S. objectives through deterrence, through engagement with allies, partners, and others, and through communicating U.S. intent. These strengths include but are not necessarily limited to those described below:

- The U.S. Army contributes to deterrence through presence, which can signal the availability of credible ground fighting capabilities in the event of conflict on the Korean Peninsula. Presence can be signaled through permanent, temporary, and rotational presence, high-level visits, and exchanges.

- The U.S. Army contributes to deterrence towards a potential adversary in an A2/AD environment through the credible presence of capabilities that enable the joint force as air and missile defense. As with ground combat capabilities, 
credible presence can be established through permanent, temporary, and rotational presence.

- The U.S. Army can and does contribute to a wide range of shaping goals by engaging in exercises with allies, partners, and others. For example:

- Operationally focused exercises with South Korean forces can be used for deterrent purposes by signaling U.S. commitment and the credible capacity of U.S. and South Korean ground forces to conduct joint and combined operations.

- Exercises involving the U.S. Army's air and missile defense capabilities can be used to help deter potential adversaries with A2/AD capabilities.

- Command post exercises can enhance and strengthen close relationships between the U.S. Army and high-capability armies such as that of Australia.

- Tabletop exercises can be used to build new relationships with armies in the region. A good example is the 2012 tabletop HA/DR exercise with the Chinese People's Liberation Army in Chengdu, China. ${ }^{230}$

- Field exercises can build better interoperability between the U.S. Army and regional armies that have medium to high capabilities, such as those of Japan, Australia, South Korea, and Indonesia.

- All types of exercises can signal U.S. Army presence as well as continued commitment to security relationships both with allies and with established and newly emerging partners. Maintaining regularly scheduled bilateral and multilateral exercises can signal continued support and commitment to partners.

- Most, if not all, exercise activities are opportunities for understanding changing partner security needs.

- Senior visits by the Chief of Staff, Army, Commander, USARPAC, and other senior officers from HQDA, TRADOC, and other commands are also important in shaping the region. Such official high-level visits can reassure allies such as Japan and the Philippines, contribute to deterring potential adversaries, build new relationships, and enhance existing relationships. Strong coordination and

230 “China, US Conclude Post-Earthquake Simulation Drill," People's Daily, online, December 3, 2012. 
consistency between USPACOM efforts and institutional Army activities are critical to further enhancing messaging and the impact of visits. ${ }^{231}$

- The U.S. Army can and does leverage its expertise to help shape through subject matter exchanges, staff assistance, training, and similar activities. The Army's considerable combat experience in recent years-and its extensive capabilities in counterinsurgency, counterterror, logistics, military medicine, air and missile defense, and so forth-makes it an attractive and effective partner for exchanges and training. TRADOC, FORSCOM, U.S. Army Medical Command (MEDCOM), the Army Corps of Engineers, and CALL have expertise that can be leveraged. ${ }^{232}$ Such exchanges can build and enhance relationships with both existing and emerging partners. Activities can easily be adjusted to match partner capabilities and security needs, whether they consist of exchanges on counterterror with the Indians, HA/DR with the Chinese, professional military education with the Malaysians, or peacekeeping operations training with the Mongolians.

- The U.S. Army Foreign Area Officer (FAO) program provides a unique and highly effective knowledge capability that U.S. military operators and planners can draw on when planning operations, actions, and activities in the region. For example, one senior U.S. officer noted that having FAOs with each of the Japanese military regional commands was vital for his ability to interact with the Japanese ground forces. ${ }^{233}$ Current Army efforts to provide non-FAO officers and cadets with regionally relevant education and training will enable the Army, the joint community, and the interagency to draw on a larger pool of subject matter experts and thereby further improve the effectiveness of shaping efforts.

- The U.S. Army National Guard State Partnership Program has proven to be a valuable tool for building relationships in the region. ${ }^{234}$ Because the program entails partnering specific Guard units with specific countries and involves the same Guardsmen repeatedly interacting with their Asian counterparts, it can be especially effective in developing long-term relations between specific units and their counterparts in the countries where they are active. ${ }^{235}$

\footnotetext{
${ }^{231}$ Interviews with U.S. Army officials, 2013.

${ }^{232}$ Ibid.

233 Ibid.

${ }^{234}$ Interviews with USPACOM officials, 2013.

${ }^{235}$ Interviews with U.S. Army officials, 2013; interviews with USPACOM officials, 2013.
} 
- Regionally Aligned Forces (RAF) provide the U.S. Army with a greater presence in the region. The Army now has RAF brigade combat teams, which, through judicious employment, can conduct actions and activities to enhance the Army's ability to engage and deter.

- The U.S. Army can also take advantage of educational institutions and programs based in the United States to shape in the Asia-Pacific region. ${ }^{236}$ For example, military educational exchanges and student exchanges can be an important means to develop basic understanding and trust that can lead to better cooperation in the future. The U.S. Army War College, the U.S. Military Academy, the U.S. Army Cadet Command, the National Defense University, and the Asia-Pacific Center for Security Studies all provide opportunities to build relationships with military personnel from China, India, Singapore, Japan, and others in the region. Obviously, Army assets do not have to be assigned to Asia to have the ability to shape the region.

- The U.S. Army can also make greater use of training facilities in the United States, such as the National Training and the Joint Readiness Training Center, to help build partner capacity. Training scenarios to address potential Army requirements in Asia should be considered.

- The Center for Army Lessons Learned collects data and after-action reports on a number of U.S. Army engagement activities in the Asia-Pacific region. Its analytical expertise can be used to train armies in the region to develop their own lessons-learned capabilities. ${ }^{237}$

All of these capabilities, programs, and institutions provide opportunities to further U.S. objectives by developing relationships through repeated interaction, both at the individual and institutional levels. They provide opportunities for the U.S. Army to develop a better understanding of the political, cultural, and social terrain, provide better insight into regional views and concerns, and afford the Army opportunity to message U.S. intent and commitment.

\section{Key considerations}

In thinking about what types of capabilities and forces it may need to provide for shaping purposes, the U.S. Army should consider the following:

\footnotetext{
${ }^{236}$ Interviews with U.S. Army officials, 2013.

${ }^{237}$ Ibid.
} 
The U.S. Army's forward presence in the region is an important part of shaping. However, a major challenge for the U.S. Army is how to develop innovative ways of demonstrating forward presence beyond those forces currently stationed in Japan and South Korea. The Army therefore should continue to develop additional means to show presence though unit rotations, temporary deployments, attaché activities, secure video teleconferencing, and exchanges of subject matter experts. USARPAC's Pacific Pathways initiative is one example of how the Army is already modifying its approach to presence in the region. ${ }^{238}$

The U.S. Army needs to continue its efforts to monitor and understand ongoing changes in the Asia-Pacific, and revise its approach to engagement as needed. In light of ongoing changes in the region discussed in the previous chapter, the Army will need to continue to understand these evolving changes and how they affect its ability to support future operations and activities. Building and retaining regional expertise remains critical to successfully adjusting to a changing security environment. Data gathered for this study reinforce the notion that Army FAOs continue to provide valuable regional expertise to the operational and institutional Army as well as the joint force and interagency. The Army's foreign area civilians are another important source of regional knowledge and provide continuity for the commands as military rotate in and out of the region. Also important are the Army's Strategic Broadening and Regional Affairs NCO programs, which provide FAO-like training and education to personnel in other tracks.

The U.S. Army should further develop its ability to assess shaping activities and lessons learned in order to take a hard look at which of its tools for shaping are most needed and most effective in the Asia-Pacific region. As the above section indicates, the Army has a wide range of capabilities, programs, and organizations that can be used for shaping in the region, whether through PACOM or through interactions with the institutional Army. However, in an environment in which there are strong budget pressures on the U.S. military and in which security issues in the Middle East continue to demand attention, it is vital to think about how best to maintain priorities.

The U.S. Army will need to continue doing its part to reassure allies and partners of continued U.S. commitment to a secure and stable environment. As noted in the previous chapter, Asian interlocutors raised doubts about the sustainability of the rebalance. Shaping these views and reassuring allies that the United States is still

\footnotetext{
${ }^{238}$ For more on Pacific Pathways, see General Vincent K. Brooks, "U.S. Army Pacific: Rebalanced and Beyond," Army, 2014 Green Book (October 2014). Available at http://www.ausa. org/publications/armymagazine/archive/2014/Documents/11November14/Brooks_GRBook20 14.pdf.
} 
capable of fulfilling its commitments, even with fewer resources, will be a key Army task in the coming years.

The U.S. Army's wealth of experience makes it a "partner of choice." Moreover, the Army's wealth of combat experience makes it a key engagement partner for any military seeking to learn from that experience. Regional militaries are interested in engaging with the Army because it is viewed as being one of the best. ${ }^{239}$ The Army can expect to be in continued demand as an engagement partner and therefore position itself to take advantage of increasing opportunities to shape.

The U.S. Army can leverage senior commanders in the Asia-Pacific region to enhance shaping in the region. For the first time since 1974, USARPAC is a four-star command-which in itself is an important message about the rebalance that can be used in shaping and engagement with China as well as allies such as Japan and emerging partners such as India. ${ }^{240}$ Further coordination of senior visits from USPACOM, HQDA, and OSD can reinforce U.S. messages of commitment and support to key countries in the region.

The U.S. Army needs to improve coordination and communication between entities engaging in the region. As HQDA, USARPAC, TRADOC, and others move individuals, delegations, and units throughout the region, each one must ensure that it understands and carries out U.S. shaping and strategic messaging goals. ${ }^{241}$

The U.S. Army should consider further expanding the Army's National Guard State Partnership Program (SPP) in the Asia-Pacific region. The Army National Guard has seven SPP relationships in the region: Alaska-Mongolia, Guam and HawaiiPhilippines, Hawaii-Indonesia, Idaho-Cambodia, Oregon-Bangladesh, Oregon-Vietnam, and Washington-Thailand. ${ }^{242}$

An important feature of this program is that exchanges between the Guard and partner countries generally involve the same ARNG units, officers, and NCOs interacting with the same Asian units year after year. ${ }^{243}$ Therefore, units and individuals form long-term relationships, which active-component individuals cannot

\footnotetext{
${ }^{239}$ Interviews with Indian military and civilian officials and think tank analysts, 2013; and transcripts, CNA Army Workshop Report, Wuthnow et al., U.S. Army in Asia: Opportunities and Challenges: Report of Workshop of Experts.

${ }^{240}$ Interviews with USPACOM officials, 2013; interviews with Japanese and South Korean defense officials, 2013.

${ }^{241}$ Interviews at U.S. Army officials, 2012 and 2013; interview with USPACOM official, 2013.

${ }^{242}$ See the "National Guard State Partnership Program," official website of the National Guard, http://www.nationalguard.mil/features/spp/default.aspx, last accessed October 29, 2013.

${ }^{243}$ Interviews with U.S. Army officials, 2013.
} 
often do. Such relationships clearly complement and enhance engagement activities by others in the region.

Moreover, the state ARNG units are made up of individuals with both civilian and military professions, which makes the Guard uniquely positioned to support wholeof-society engagement. In this way, the ARNG can help the U.S. Army shape countries in support of U.S. objectives beyond those in the military realm. Interviews indicate that there is support within the ARNG to engage in such whole-of-society engagement. ${ }^{244}$

\section{Concluding thoughts and recommendations}

In conclusion, the U.S. Army will continue to play a vital role in support of U.S. national objectives in the Asia-Pacific region, as it has since 1898. The Army can and does contribute to the U.S. military's ability to maintain the regional stability that the U.S. and regional economies depend on. The Army also supports U.S. national efforts to maintain a rules-based environment, protect U.S. interests and commitments throughout the region, shape the regional environment, and help protect the U.S. homeland.

One way the U.S. Army provides this support is by being prepared to fight, if necessary, in the Asia-Pacific region. This means that the Army needs to continue to be able to deter, conduct major combat operations, and engage in post-conflict operations on the Korean Peninsula against a nuclear armed opponent-North Korea. It also means that the Army should be prepared to complement the joint force in an $\mathrm{A} 2 / \mathrm{AD}$ environment against a hostile opponent. In Asia, therefore, the Army needs to have the capabilities to participate in both types of conflict, and needs either to have the required capabilities already present in theater or to be able to move those capabilities quickly into the region.

The U.S. Army also supports U.S. national objectives by enabling the joint force and interagency to respond to natural disasters and other non-traditional threats throughout the region. The Army brings the ability to work with other militaries; it provides critical command and communication skills; and it offers the logistical, engineering, civil affairs, military police, medical, and other skills which support and enable the U.S. government's efforts throughout the Asia-Pacific region.

Finally, and crucially, the U.S. Army supports U.S. national objectives in the region through its ability to shape. The Army shapes through engagement, and it shapes

${ }^{244}$ Ibid. 
through its ability to deter. It can deter through presence, through exercises, and through strategic communication. It has a wide range of capabilities and assets that it can use in order to engage with countries in the region, and it has the ability to tailor the size and types of capabilities used in engagement in order to fit the needs and sensitivities of the various countries. It also has, and should further build on, the knowledge assets (such as the FAO program) that it needs in order to better understand the countries with which it interacts.

In order to continue to support U.S. national security objectives in the region, the U.S. Army will need to retain a broad range of capabilities that allow it to fight traditional ground wars, contribute to the joint force in an $\mathrm{A} 2 / \mathrm{AD}$ environment, respond to a wide range of non-traditional threats to U.S. interests and allies, and engage with most of the countries of the region-allies, partners, emerging powers, and China. In order to do this, the Army must think carefully about what balance of assets and capabilities is best, it must get those assets to where they are needed, and it must have officers and enlisted personnel who have knowledge of the region and the countries within which the Army must operate to ensure success.

\section{Recommendations}

In order to help ensure that the U.S. Army continues to have the capabilities to fulfill its role in the region, we offer the following recommendations:

\section{Revisit capacity.}

Revisit the balance of "fight, enable, and shape" capabilities it needs in order to meet its Asia-Pacific requirements.

- If it has not done so, the U.S. Army should conduct an Army-wide review to assess what operational units and institutional organizations are specifically doing both in theater and in the continental United States. The Army could use this review to re-examine (1) what assets are available for use, (2) whether they are properly aligned, and (3) where the Army will need to take risk.

\section{Leverage different ways it can maintain forward presence and visibility in the region.}

- With the assignment of a four-star general to USARPAC and the availability of regionally aligned forces, new means are available to leverage capability. The U.S. Army should take a new look at how best to leverage (1) individual and unit rotations, (2) temporary deployments, (3) attaché activities, (4) security cooperation entities, (5) institutional exchanges, (6) video teleconferences, and (7) synthetic training capabilities. By doing so, it can optimize its efforts to assure presence, especially among key partners throughout Southeast Asia. 
Work with OSD and the joint community to revisit the location and composition of pre-positioned (PREPO) equipment so that it is closer to where it will most likely be needed in the evolving operational environment.

- The U.S. Army should continue to push for off-shore prepositioning, especially with regard to Southeast Asia and South Asia, in order to reset the theater and PREPO stocks with engagement requirements and non-traditional threats in mind.

Manage and communicate future U.S. Army force posture changes with an eye to how these will be perceived in the region.

- Especially within the context of the rebalance to Asia and persistent concerns about U.S. commitment, any reductions or realignments of U.S. Army forces in Asia should be accompanied by a solid strategic communications plan.

2. Build processes and further develop relationships.

Re-examine how best to synchronize U.S. Army efforts in the Asia-Pacific region.

- As the U.S. Army participates in a host of operational and institutional engagements with multiple partners, increased coordination among organizations will be instrumental in maximizing the Army's unity of effort and impact in the region.

Develop standard or cross-Army metrics and methodologies to measure success in an engagement and assess its effects on shaping.

- The results of these assessments should be disseminated and incorporated into plans for future operational and institutional engagements.

Leverage U.S. Army experiences in Afghanistan and Iraq when reaching out to armies that need counterterrorist, counterinsurgency, and internal security training.

- Regional militaries are interested in engaging with the U.S. Army because it is viewed as being one of the best and a "partner of choice." In dealing with regional armies, the Army should highlight what it can bring based on its experiences.

Reinforce success by expanding the Army National Guard (ARNG) State Partnership Program (SPP) in the Asia-Pacific region beyond its current seven ARNG-country relationships.

- As a civil-military organization, the Army National Guard, through its SPP, is uniquely positioned to promote whole-of-society, cooperative engagements 
that allow the United States to interact with regional civilian authorities where appropriate.

\section{Build and retain critical regional expertise.}

Re-examine the Asia-Pacific FAO program to make sure the U.S. Army has the right mix of FAOs needed to support its ability to fight, enable, and shape.

- Such an assessment should revisit whether the current system to identify, train, assign, and retain FAOs is meeting evolving service, joint, and interagency needs. Increasing non-traditional demands and requirements in South and Southeast Asia should be considered in any decisions to realign FAOs who are being trained and assigned to the region.

Reassess ways to further build non-FAO regional expertise.

- As there is unlikely to be a significant growth in the number of FAOs available for Asia in the near future, the U.S. Army should also identify how best to promote regional expertise among non-FAO personnel-including officers, NCOs, enlisted soldiers, and civilian personnel-by developing, assigning, and retaining them in a way that boosts the Army's capabilities in Asia.

Revisit how ROTC and USMA cultural and foreign language immersion programs can play a greater role in building regional expertise.

- The U.S. Army may be able to build its future regional expertise by identifying cadets involved in Asia-Pacific exchange programs, joint exercise support, and language training, and finding ways to build on their experiences.

Expand the reading lists of the Chief of Staff of the Army and other commands, to include books and articles aimed at improving their understanding of the history, culture, and current issues relevant to the Asia-Pacific region.

- The U.S. Army has been focused on the wars in Afghanistan and Iraq. As it shifts to support the rebalance to Asia, its officers, enlisted personnel, and civilians will need to be more cognizant of the strategic environment and the challenges they will be facing. 
This page intentionally left blank. 


\section{The CNA Corporation}

This report was written by CNA Corporation's China 中 Studies (CHS) division.

CHS conducts nonpartisan, objective, evidence-based analyses of developments within China, of China's emerging role in the international order, and of issues related to U.S.-China relations. Its analysts provide the insight and context leaders need to make informed decisions, develop effective plans, and implement sound policies.

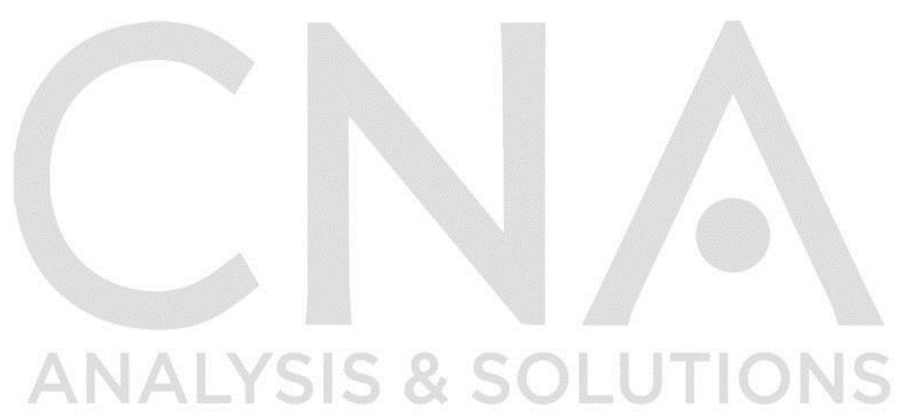




\section{CRM-2015-U-010431-Final}

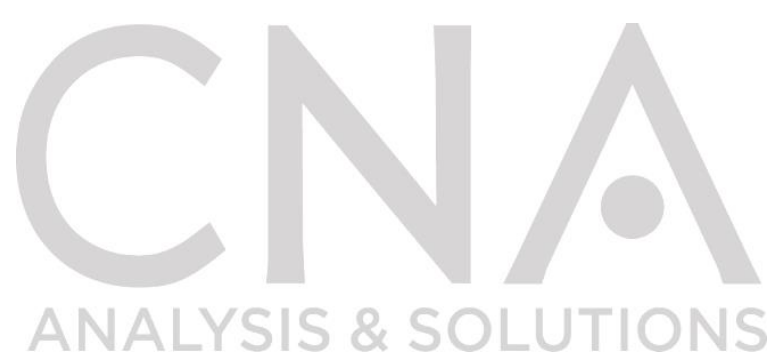

CNA Corporation is a not-for-profit research organization that serves the public interest by providing in-depth analysis and result-oriented solutions to help government leaders choose the best course of action in setting policy and managing operations.

Nobody gets closer-

to the people, to the data, to the problem. 